\title{
An Evaluation of High Temperature Airframe Seals for Advanced Hypersonic Vehicles
}

Jeffrey J. DeMange

The University of Toledo, Toledo, Ohio

Patrick H. Dunlap and Bruce M. Steinetz

Glenn Research Center, Cleveland, Ohio

Gary J. Drlik

Analex Corporation, Brook Park, Ohio 


\section{NASA STI Program . . . in Profile}

Since its founding, NASA has been dedicated to the advancement of aeronautics and space science. The NASA Scientific and Technical Information (STI) program plays a key part in helping NASA maintain this important role.

The NASA STI Program operates under the auspices of the Agency Chief Information Officer. It collects, organizes, provides for archiving, and disseminates NASA's STI. The NASA STI program provides access to the NASA Aeronautics and Space Database and its public interface, the NASA Technical Reports Server, thus providing one of the largest collections of aeronautical and space science STI in the world. Results are published in both non-NASA channels and by NASA in the NASA STI Report Series, which includes the following report types:

- TECHNICAL PUBLICATION. Reports of completed research or a major significant phase of research that present the results of NASA programs and include extensive data or theoretical analysis. Includes compilations of significant scientific and technical data and information deemed to be of continuing reference value. NASA counterpart of peer-reviewed formal professional papers but has less stringent limitations on manuscript length and extent of graphic presentations.

- TECHNICAL MEMORANDUM. Scientific and technical findings that are preliminary or of specialized interest, e.g., quick release reports, working papers, and bibliographies that contain minimal annotation. Does not contain extensive analysis.

- CONTRACTOR REPORT. Scientific and technical findings by NASA-sponsored contractors and grantees.
- CONFERENCE PUBLICATION. Collected papers from scientific and technical conferences, symposia, seminars, or other meetings sponsored or cosponsored by NASA.

- SPECIAL PUBLICATION. Scientific, technical, or historical information from NASA programs, projects, and missions, often concerned with subjects having substantial public interest.

- TECHNICAL TRANSLATION. Englishlanguage translations of foreign scientific and technical material pertinent to NASA's mission.

Specialized services also include creating custom thesauri, building customized databases, organizing and publishing research results.

For more information about the NASA STI program, see the following:

- Access the NASA STI program home page at http://www.sti.nasa.gov

- E-mail your question via the Internet to help@sti.nasa.gov

- Fax your question to the NASA STI Help Desk at 301-621-0134

- Telephone the NASA STI Help Desk at 301-621-0390

- Write to: NASA Center for AeroSpace Information (CASI) 7115 Standard Drive Hanover, MD 21076-1320 


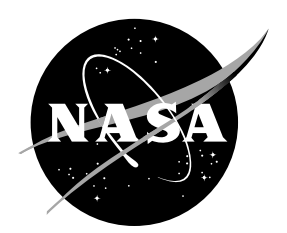

\section{An Evaluation of High Temperature Airframe Seals for Advanced Hypersonic Vehicles}

Jeffrey J. DeMange

The University of Toledo, Toledo, Ohio

Patrick H. Dunlap and Bruce M. Steinetz

Glenn Research Center, Cleveland, Ohio

Gary J. Drlik

Analex Corporation, Brook Park, Ohio

Prepared for the

43rd Joint Propulsion Conference and Exhibit

cosponsored by the AIAA, ASME, SAE, and ASEE

Cincinnati, Ohio, July 8-11, 2007

National Aeronautics and

Space Administration

Glenn Research Center

Cleveland, Ohio 44135 


\section{Acknowledgments}

The authors would like to acknowledge the technical contributions of Brian Zuchowski (Lockheed Martin Corporation) and the support of the Lockheed Martin Corporation. Special thanks are also given to Richard Tashjian for his valuable advice and technical support.

Trade names and trademarks are used in this report for identification only. Their usage does not constitute an official endorsement, either expressed or implied, by the National Aeronautics and Space Administration.

Level of Review: This material has been technically reviewed by technical management.

Available from

NASA Center for Aerospace Information 7115 Standard Drive

Hanover, MD 21076-1320
National Technical Information Service 5285 Port Royal Road Springfield, VA 22161 


\title{
An Evaluation of High Temperature Airframe Seals for Advanced Hypersonic Vehicles
}

\author{
Jeffrey J. DeMange \\ The University of Toledo \\ Toledo, Ohio 43606 \\ Patrick H. Dunlap and Bruce M. Steinetz \\ National Aeronautics and Space Administration \\ Glenn Research Center \\ Cleveland, Ohio 44135 \\ Gary J. Drlik \\ Analex Corporation \\ Brook Park, Ohio 44135
}

\begin{abstract}
High temperature seals are required for advanced hypersonic airframe applications. In this study, both spring tube thermal barriers and innovative wafer seal systems were evaluated under relevant hypersonic test conditions (temperatures, pressures, etc.) via high temperature compression testing and room temperature flow assessments. Thermal barriers composed of a René 41 spring tube filled with Saffil insulation and overbraided with a Nextel 312 sheath showed acceptable performance at $1500{ }^{\circ} \mathrm{F}$ in both short term and longer term compression testing. Nextel 440 thermal barriers with René 41 spring tubes and Saffil insulation demonstrated good compression performance up to $1750{ }^{\circ} \mathrm{F}$. A silicon nitride wafer seal/compression spring system displayed excellent load performance at temperatures as high as $2200^{\circ} \mathrm{F}$ and exhibited room temperature leakage values that were only $1 / 3$ those for the spring tube rope seals. For all seal candidates evaluated, no significant degradation in leakage resistance was noted after high temperature compression testing. In addition to these tests, a superalloy seal suitable for dynamic seal applications was optimized through finite element techniques.
\end{abstract}

\section{Nomenclature}

$\begin{array}{ll}\sigma_{\max } & \text { Maximum stress } \\ \mathrm{E} & \text { Young's modulus } \\ \omega_{\max } & \text { Maximum half-deflection on end } \\ \mathrm{t} & \text { Material thickness } \\ \mathrm{L} & \text { Length of beam element }\end{array}$

\section{Introduction}

Advanced hypersonic vehicles require seals along actuated control surfaces as well as in the joints between airframe thermal protection panels. These seals are necessary to limit the ingestion of high temperature gases into the gaps between panels or in control surface locations, thereby protecting internal temperature-sensitive components and structures. Incursion of high temperature gases into vulnerable areas could result in reduced vehicle stability or potentially even loss of the vehicle and crew.

The NASA Glenn Research Center (GRC) has established expertise in the development of high temperature seals such as those needed for advanced hypersonic applications. Efforts in recent years have included improvement of the baseline control surface thermal barrier developed during the initial Space Shuttle design phase, as well as advancement of a unique wafer seal design conceived during the National Aerospace Plane (NASP) program in the early 1990’s.

The baseline control surface spring tube seal has a nominal diameter of about 0.62 to 0.69 in. and consists of an Inconel X-750 (Special Metals Corp., Huntington, WV) spring tube stuffed with Saffil (Saffil Ltd., Widnes, Cheshire UK) batting and overbraided with two layers of Nextel 312 (3M, St. Paul, MN) ceramic sleeving (Figure 1). Unfortunately these seals lose their resiliency and take on a large permanent set when they are 
compressed at high temperatures (Figure 1). Permanent set limits the ability of a seal to conform to movements of the opposing sealing surface caused by structural and thermal loads and increases the chance of hot gas flow past the seal. Previous research at GRC demonstrated a marked improvement in resiliency of the spring tube when René 41 (ATI Properties, Inc., Monroe, NC) wire was used as a replacement for the Inconel X-750. ${ }^{1,2}$ Additional testing on a full construction seal design incorporating the René 41 spring tube also exhibited some enhancement, though not to the degree observed with the spring tube by itself. ${ }^{3}$

A ceramic wafer seal has also been under development for several years at GRC (Figure 2). Although primarily envisioned as a durable, low-leakage seal for propulsion system applications, this seal technology could also be used in challenging dynamic control surface applications with extreme temperatures. This seal is composed of a series of thin ceramic wafers installed in a channel and preloaded from behind to maintain contact with the opposing sealing surface. The wafers are able to seal against distorted surfaces by sliding past each other to conform to the shape of the surface. Preload devices include high temperature canted coil springs and compression springs. A study performed by Dunlap, et al. showed that a system composed of monolithic silicon nitride wafers (Honeywell AS800) and silicon nitride compression springs was an excellent candidate to meet the sealing needs of future hypersonic vehicles. ${ }^{4}$ Flow rates for these wafers were significantly lower than those measured for the best textilebased seals even after 1000 scrub cycles against monolithic silicon carbide at $2000^{\circ} \mathrm{F}$.

Researchers at GRC are currently assisting with the development of airframe seals for an advanced hypersonic vehicle. An illustration of a representative hyper-sonic vehicle is presented in Figure 3. Both spring tube thermal barriers and ceramic wafer seals are considered as prime candidates for several critical airframe locations on this vehicle. In order to determine suitability of these seals, GRC conducted critical function performance tests for two evolving designs of this

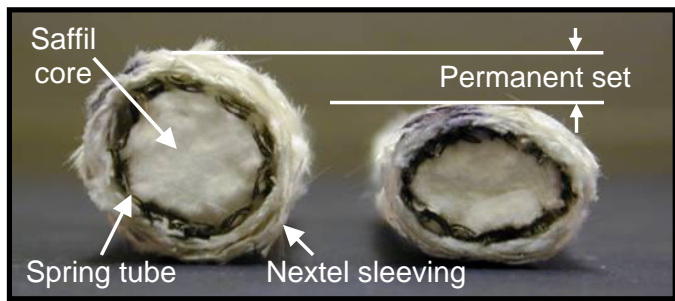

Figure 1.-Photograph showing permanent set in baseline control surface spring tube seal after $30 \%$ compression at $1900^{\circ} \mathrm{F}$.

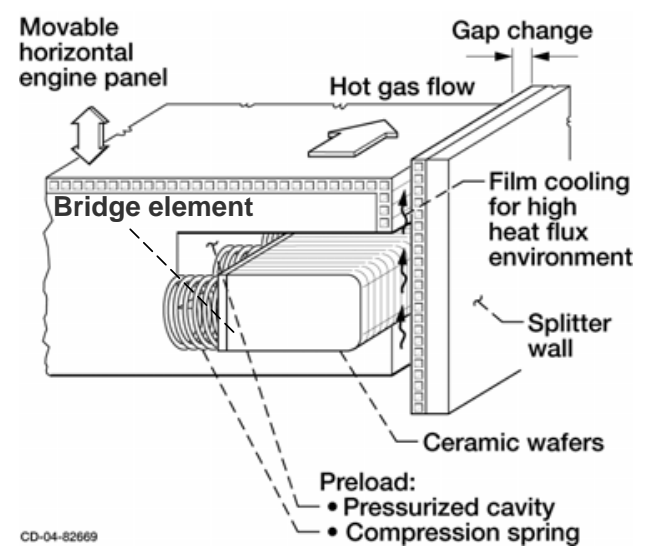

Figure 2.-Schematic of wafer seals with compression springs as preloading devices.

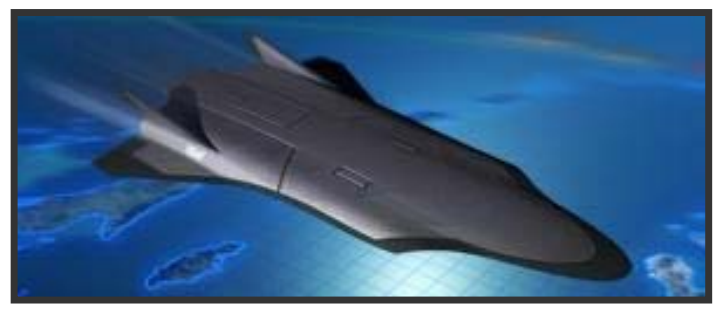

Figure 3.-Conceptual image of an advanced hypersonic cruise vehicle.

vehicle (Vehicle Designs A and B). The primary objective of these tests was to assess seal performance under relevant hypersonic conditions (temperatures, pressures, compression levels, exposure durations, etc.).

\section{Experimental Procedure}

\section{A. Test Samples}

\section{Nextel 312 Seals}

A $10 \mathrm{ft}$ length of high temperature spring tube thermal barrier was manufactured by Jackson-Bond Enterprises, LLC (Dover, NH). The seal was constructed using a 0.5-in. thick Saffil blanket inserted into a spring tube made from René 41 ( $0.560 \pm 0.025$-in. diameter). The amount of Saffil was selected to yield a density of approximately 7 pounds per cubic foot (pcf) of seal. The spring tube was supplied to Jackson-Bond in a heat treated state using the NASA R41C heat treatment $\left(2050^{\circ} \mathrm{F}\right.$ for $0.5 \mathrm{hr}$ and then $1400^{\circ} \mathrm{F}$ for $16 \mathrm{hr}$ ). This construction was then inserted into two layers of sleeving made from served Nextel 312 yarn to generate a final diameter of approximately 0.69 in. Seals constructed as described above are herein referred to as CS-1.

Prior to testing, nominal 4 -in. samples were cut from the $10-\mathrm{ft}$ length of seal, and these specimens were heat cleaned at $900{ }^{\circ} \mathrm{F}$ for $15 \mathrm{hr}$ to remove any organic materials (i.e., binders, etc.). Although this heating schedule was 
not the preferred cleaning method for Nextel, the parameters were selected to minimize any adverse temperature effects on the metallic spring tubes.

\section{Nextel 440 Seals}

A second $10 \mathrm{ft}$ length of seal, denoted as CS-2, was also manufactured by Jackson-Bond Enterprises, LLC using an identical method to that for the Nextel 312 seals except that Nextel 440 was used as the sheath material. Nominal 4-in. samples were cut from the $10-\mathrm{ft}$ length of seal, and these specimens were heat cleaned at $900{ }^{\circ} \mathrm{F}$ for $15 \mathrm{hr}$ to remove any organic materials prior to testing. Table 1 provides nominal material compositions for each of the components in the two seal designs.

Table 1.-Nominal material compositions for seal components.

\begin{tabular}{|c|c|c|c|c|c|c|c|c|c|}
\hline Component & $\begin{array}{c}\text { Seal } \\
\text { Desianation }\end{array}$ & Material & \multicolumn{7}{|c|}{ Nominal Composition } \\
\hline \multirow{2}{*}{ Sheath } & CS-1 & $\begin{array}{c}\text { Nextel } \\
312\end{array}$ & $\begin{array}{c}62 \% \\
\mathrm{Al}_{2} \mathrm{O}_{3}\end{array}$ & $\begin{array}{l}24 \% \\
\mathrm{SiO}_{2}\end{array}$ & $\begin{array}{l}14 \% \\
\mathrm{~B}_{2} \mathrm{O}_{3}\end{array}$ & & & & \\
\hline & CS-2 & $\begin{array}{l}\text { Nextel } \\
440\end{array}$ & $\begin{array}{c}70 \% \\
\mathrm{Al}_{2} \mathrm{O}_{3}\end{array}$ & $\begin{array}{l}28 \% \\
\mathrm{SiO}_{2}\end{array}$ & $\begin{array}{c}2 \% \\
\mathrm{~B}_{2} \mathrm{O}_{3}\end{array}$ & & & & \\
\hline Spring Tube & CS-1, CS-2 & Rene 41 & $\begin{array}{c}18-20 \% \\
\mathrm{Cr}\end{array}$ & $\begin{array}{c}9-10.5 \% \\
\text { Mo }\end{array}$ & $\begin{array}{c}10-12 \% \\
\text { Co }\end{array}$ & $\begin{array}{c}3-3.3 \% \\
\mathrm{Ti}\end{array}$ & $\begin{array}{c}1.4-1.8 \% \\
\mathrm{Al}\end{array}$ & $\begin{array}{c}5 \% \max \\
\mathrm{Fe}\end{array}$ & $\begin{array}{c}\mathrm{Bal} \\
\mathrm{Ni}\end{array}$ \\
\hline Core & CS-1, CS-2 & Saffil & $\begin{array}{c}95-97 \% \\
\mathrm{Al}_{2} \mathrm{O}_{3}\end{array}$ & $\begin{array}{l}3-5 \% \\
\mathrm{SiO}_{2}\end{array}$ & & & & & \\
\hline
\end{tabular}

\section{Wafer Seals and Preloaders}

Silicon nitride wafer seals were fabricated from Honeywell AS-800 with a nominal sample size of 0.909 in. by $0.500 \mathrm{in}$. by $0.125 \mathrm{in}$. for each wafer. Before testing, a stack of 31 wafers was "gang-ground" using a diamond grinding wheel so that individual wafer heights were within \pm 0.0005 in. of each other. The stack of seals was preloaded by four custom $\mathrm{Si}_{3} \mathrm{~N}_{4}$ compression springs manufactured by NHK Spring Co., LTD. The springs had a nominal wire diameter of 0.055 in., an overall outer diameter of $0.475 \mathrm{in}$., and a free height of $0.745 \mathrm{in}$. The stiffness of the springs was approximately $50 \mathrm{lbf} / \mathrm{in}$.

\section{Metallic Channel Seal}

A channel seal is being considered for a torque tube dynamic sealing application as part of the design efforts for these advanced hypersonic vehicles. The baseline test seal configuration is shown in Figure 4 and consisted of a thin superalloy metallic sheet bent into a C-shaped configuration. As illustrated, two holes were incorporated on the back face to permit attachment of the channel seal. A partial overlay reinforced laminate channel seal (Figure 5) was also investigated to minimize stresses while maintaining adequate seal preload. Finite element analyses (FEA) were performed on several design iterations of these two seal types in order to evaluate the effects of seal configuration, sheet material, applied load, and anchoring technique on maximum stresses at high temperature.

\section{B. Test Equipment}

\section{Flow Fixture}

Room temperature flow tests were conducted on the seals before and after compression testing using the test fixture shown in Figure 6. This rig consists of an aluminum base, an 
aluminum seal holder to hold the test specimen, and a spacer plate used to set the flow gap (i.e., seal exposure height). For the spring tube seal tests, the seal holder contained a 0.660 -in. wide by 4.000 -in. long by 0.625 -in. deep groove. For the wafer tests, the specimens were installed in a seal holder containing a 0.502 -in. wide by 4.000 -in. long, by 1.780 -in. deep groove. Appropriate shims were placed behind the seals to ensure the proper amount of compression. In both cases, the nominal gap was set to 0.100 in. using an appropriate spacer plate. The fixture also used an aluminum cover plate containing a 4 by 7 by 0.1 in. ceramic matrix composite (CMC) panel against which the seal is mated to better simulate actual airframe surfaces. For the current tests, a carbon/carbon (C/C) test panel (C-CAT, Ft. Worth, TX) was used. This panel had a nominal surface roughness of approximately $75 \mu$ in.

After the test specimen was inserted into the holder and the fixture was fully assembled, the seal was flow tested using shop air. Pressure was monitored using a Setra 239 pressure transducer ( 5 psid, 0.14\% FS accuracy), and flow rates were measured using a Hastings HFM 201 flowmeter (3.5 SCFM, 1\% FS accuracy). For safety reasons, any fibers liberated during flow testing were collected using a HEPA-rated collector.

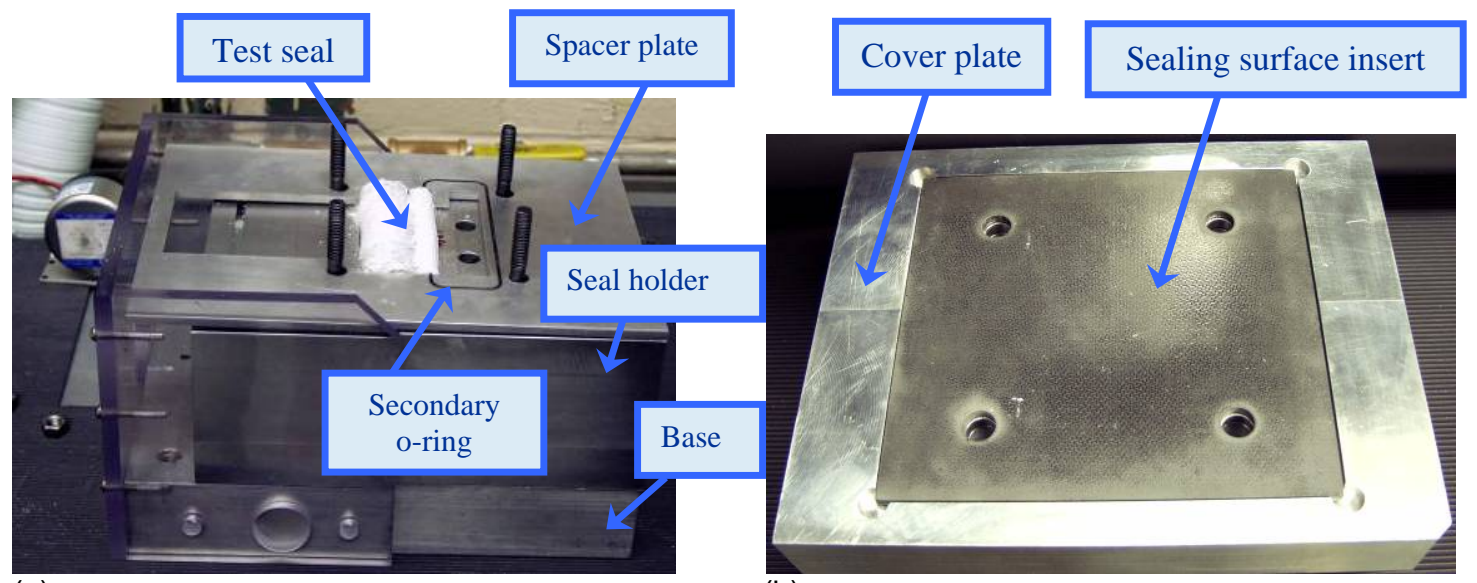

(a)

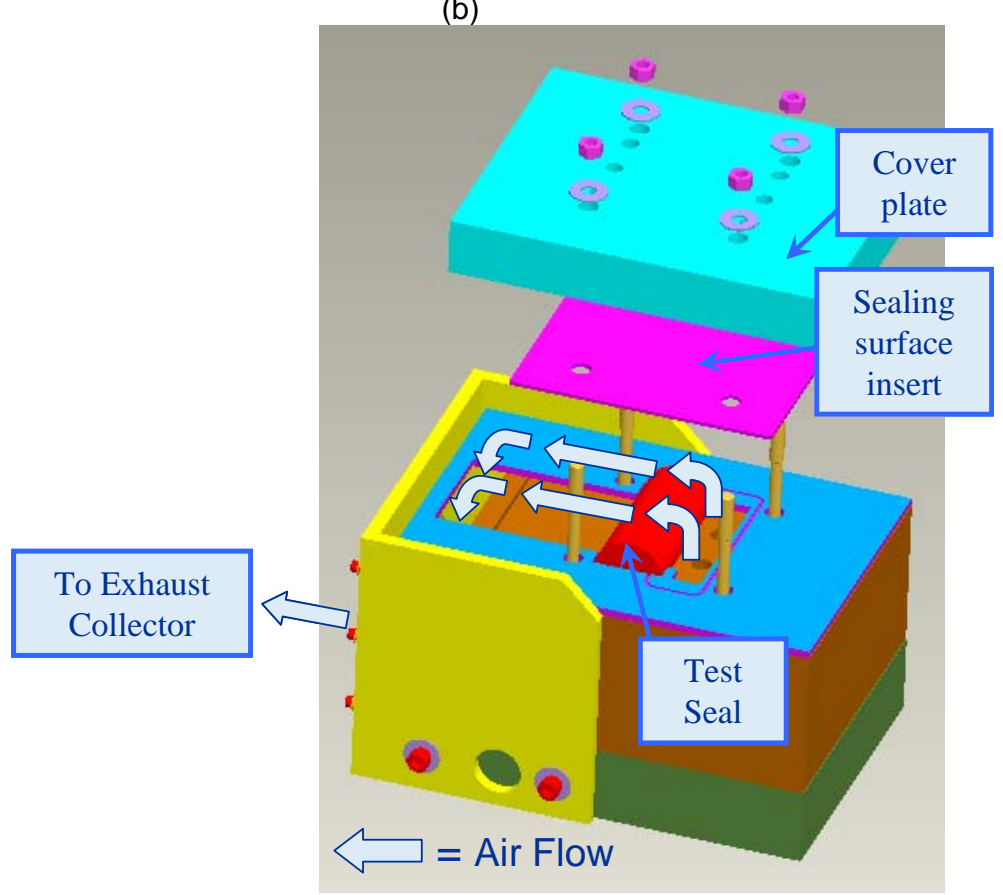

(c)

Figure 6.-(a) Picture of flow fixture seal holder, spacer plate and test sample, (b) photo of flow fixture cover plate with sealing surface insert and (c) schematic of flow fixture in an exploded view showing air flow. 


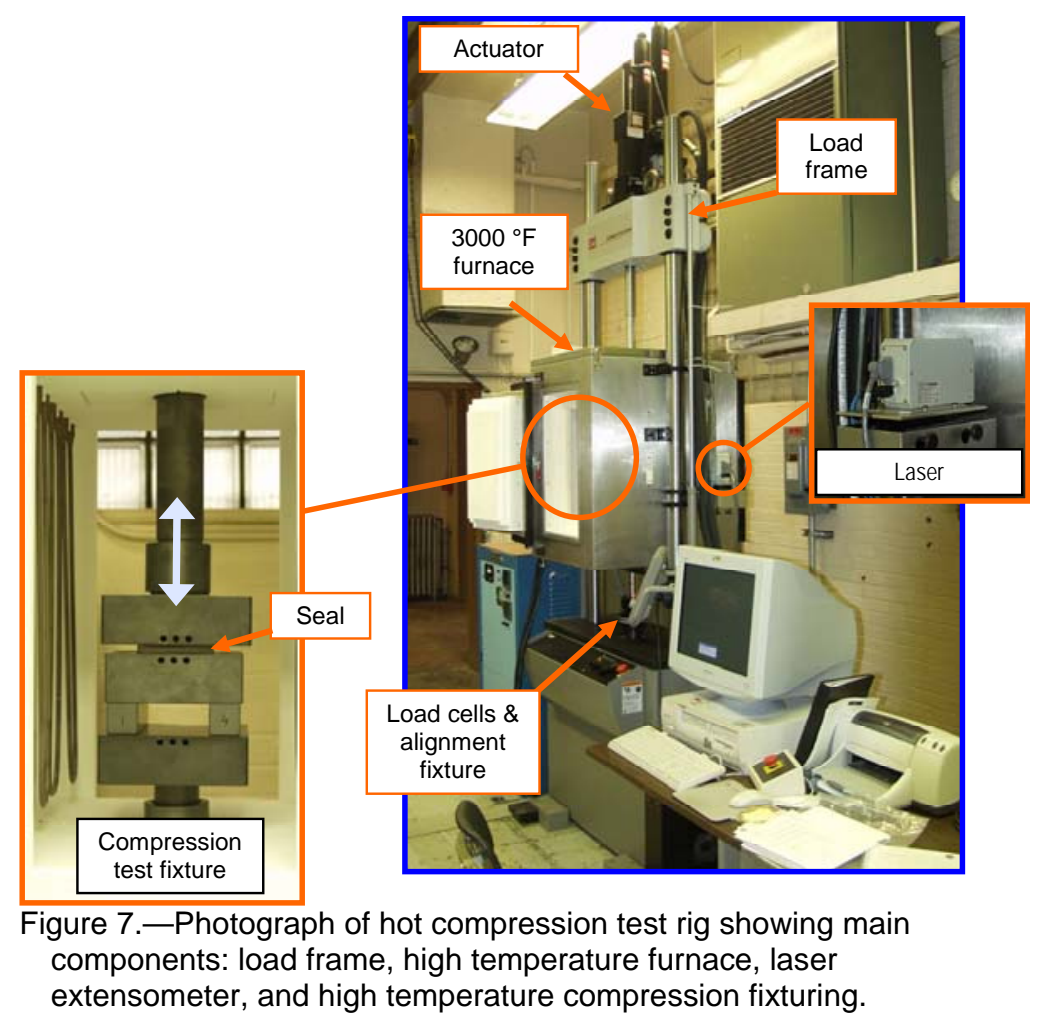

\section{High Temperature Compression Rig}

The seal specimens were compression tested in a state-of-the-art Hot Compression/Scrub Rig located at GRC (Figure 7). This rig consists of a servohydraulic test frame, a custom $3000^{\circ} \mathrm{F}$ box air furnace, and a non-contact laser extensometer. For the current tests, a $100 \mathrm{lbf}$ load cell was for used for measuring load (accuracy $\pm 0.05 \mathrm{lbf}$ ), and the laser extensometer (accuracy \pm 0.00025 in.) was used for evaluating the amount of compression on the seals. Further details of the test rig can be found in the paper by Dunlap, et al. ${ }^{5}$

\section{Test Procedures}

\section{Nextel 312 Seal Tests}

Short Term Tests for Vehicle Design A.-High temperature compression tests were conducted on 4-in. lengths of the Nextel 312 spring tube seals. A primary test and two repeat tests were performed for each test cycle. A test cycle consisted of three separate compression tests as well as an initial flow evaluation and flow tests after each compression evaluation. For example, the test cycle conducted on seal CS-1-13 consisted of the steps shown in Table 2. A full summary of all the tests is provided in Table 2.-Test sequence used for short term tests.

\begin{tabular}{|l|c|c|c|}
\hline \multicolumn{1}{|c|}{ Type of Test } & Delta P & Dwell & Cycles \\
\hline Flow (RT) & $2.0 \mathrm{psig}$ & --- & --- \\
\hline Compression $\left(1500^{\circ} \mathrm{F}\right)$ & --- & $3000 \mathrm{~s}$ & 1 \\
\hline Flow $(\mathrm{RT})$ & $2.0 \mathrm{psig}$ & --- & --- \\
\hline Compression $\left(1500^{\circ} \mathrm{F}\right)$ & --- & $2200 \mathrm{~s}$ & 1 \\
\hline Flow $(\mathrm{RT})$ & $2.0 \mathrm{psig}$ & --- & --- \\
\hline Compression $\left(1500^{\circ} \mathrm{F}\right)$ & --- & $200 \mathrm{~s}$ & 4 \\
\hline Flow $(\mathrm{RT})$ & $2.0 \mathrm{psig}$ & --- & --- \\
\hline
\end{tabular}
Table 3.

The seals were flow tested in the fixture previously described. Prior to testing, each seal sample was installed into the groove, and the height of the sample above the holder was measured in three locations along the length of the seal. The height of the $\mathrm{C} / \mathrm{C}$ panel was also measured to ensure that it was flush to within $+0.003 /-0.000$ in. when installed in the pocket of the cover plate. After ensuring everything was properly installed, the flow fixture was fully assembled, and the leakage for each specimen was assessed up to 2.0 psid in 0.1 psid pressure increments.

For each compression test, the 4-in. seal specimen from the aforementioned flow test was first installed in a SiC seal holder with a 0.660-in. wide groove. Appropriate shims were placed underneath the seal to produce a nominal 0.100 -in. gap between the seal holder and top platen when the seal was compressed $20 \%$. The holder containing the seal was then installed inside the furnace, and the sample was heated to $1500^{\circ} \mathrm{F}$ at a rate of $500{ }^{\circ} \mathrm{F} / \mathrm{hr}$. 
For the first compression test of the sequence, the upper platen was lowered to achieve initial contact (defined as $0.05 \mathrm{lbf} / \mathrm{in}$. of seal) after the appropriate temperature was reached. Care was exercised to ensure minimal fraying of the end fibers which might affect uniform contact conditions. The seal was then loaded at $0.002 \mathrm{in} . / \mathrm{s}$ to $20 \%$ compression ( 0.135 in.), held for the duration shown in Table 3, and then fully unloaded at $0.002 \mathrm{in./s}$. After each compression test, the seal was photographed and dimensionally measured and then inserted into the flow fixture for a leakage test. For each subsequent compression test in the test sequence, the seal was re-installed into the SiC compression fixture and inserted into the furnace. After achieving the temperature, the load platen was returned to the same starting position used in the first compression test (3000 s dwell). The platen was then moved $0.135 \mathrm{in}$. toward the seal at $0.002 \mathrm{in} . / \mathrm{s}$, held for the appropriate duration, and then unloaded to the starting point at the same rate. For the last compression test (200 s dwell), this load cycle was repeated 3 additional times.

Table 3.-Summary of parameters used for compression testing of spring tube seals.

\begin{tabular}{|c|c|c|c|c|c|c|c|c|c|}
\hline \multirow[t]{2}{*}{ Seal Construction } & \multirow[t]{2}{*}{ Seal ID } & \multirow{2}{*}{$\begin{array}{c}\text { Test } \\
\text { Sequence }\end{array}$} & \multirow[t]{2}{*}{ Test ID } & \multirow{2}{*}{$\begin{array}{c}\begin{array}{c}\text { Test } \\
\text { Temperature }\end{array} \\
\left({ }^{\circ} \mathrm{F}\right)\end{array}$} & \multirow{2}{*}{\begin{tabular}{|c|} 
Compression \\
$(\%)$ \\
\end{tabular}} & \multirow[t]{2}{*}{ Cycles } & \multirow[t]{2}{*}{ Duration } & \multicolumn{2}{|c|}{$\begin{array}{c}\text { Room Temp. } \\
\text { Flow Tests }\end{array}$} \\
\hline & & & & & & & & Before & After \\
\hline \multicolumn{10}{|c|}{ Short Term Tests Vehicle Design A } \\
\hline \multirow{9}{*}{ 2L N312/ Rene 41/ 7 pcf Saffil } & \multirow{3}{*}{ CS-1-13 } & \multirow{3}{*}{ TS1 } & C17 & 1500 & 20 & 1 & $3000 \mathrm{~s}$ & $\mathrm{x}$ & $x$ \\
\hline & & & $\mathrm{CX} 1$ & 1500 & 20 & 1 & $2200 \mathrm{~s}$ & & $x$ \\
\hline & & & C18 & 1500 & 20 & 4 & $200 \mathrm{~s}$ & & $\mathrm{x}$ \\
\hline & \multirow{3}{*}{ CS-1-9 } & \multirow{3}{*}{ TS2 } & $\mathrm{CX} 2$ & 1500 & 20 & 1 & $3000 \mathrm{~s}$ & $\mathrm{x}$ & $\mathrm{x}$ \\
\hline & & & C19 & 1500 & 20 & 1 & $2200 \mathrm{~s}$ & & $\mathrm{x}$ \\
\hline & & & $\mathrm{C} \times 3$ & 1500 & 20 & 4 & $200 \mathrm{~s}$ & & $\mathrm{x}$ \\
\hline & \multirow{3}{*}{ CS-1-14 } & \multirow{3}{*}{ TS3 } & CX6 & 1500 & 20 & 1 & $3000 \mathrm{~s}$ & $x$ & $\mathrm{x}$ \\
\hline & & & $\mathrm{CX} 7$ & 1500 & 20 & 1 & $2200 \mathrm{~s}$ & & $\mathrm{x}$ \\
\hline & & & CX8 & 1500 & 20 & 4 & $200 \mathrm{~s}$ & & $\mathrm{x}$ \\
\hline \multicolumn{10}{|c|}{ Long Term Tests Vehicle Design A } \\
\hline \multirow{4}{*}{ 2L N312/ Rene 41/ 7 pcf Saffil } & \multirow{2}{*}{ CS-1-15 } & \multirow{2}{*}{ LT1 } & \multirow{2}{*}{ C14 } & 70 & 20 & 1 & 60 days & $\mathrm{x}$ & $\mathrm{x}$ \\
\hline & & & & 1500 & 20 & 1 & $2200 \mathrm{~s}$ & & $x$ \\
\hline & \multirow{2}{*}{ CS-1-20 } & \multirow{2}{*}{ LT2 } & \multirow{2}{*}{$\mathrm{C} 15$} & 70 & 20 & 1 & 60 days & $\mathrm{x}$ & $\mathrm{X}$ \\
\hline & & & & 1500 & 20 & 1 & $2200 \mathrm{~s}$ & & $\mathrm{x}$ \\
\hline \multicolumn{10}{|c|}{ Short Term Tests Vehicle Design B } \\
\hline \multirow{6}{*}{ 2L N440/ Rene 41/ 7 pcf Saffil } & CS-2-6 & --- & $\mathrm{CX} 4$ & 70 & 20 & 4 & $1800 \mathrm{~s}$ & $\mathrm{x}$ & $\mathrm{x}$ \\
\hline & CS-2-11 & --- & $\mathrm{CX5}$ & 1500 & 20 & 4 & $1800 \mathrm{~s}$ & $x$ & $x$ \\
\hline & CS-2-12 & --- & $\mathrm{C} 22$ & 1500 & 20 & 2 & $3600 \mathrm{~s}$ & $x$ & $x$ \\
\hline & CS-2-14 & --- & $\mathrm{C} 27$ & 1500 & 25 & 2 & $3600 \mathrm{~s}$ & $\mathrm{X}$ & $\mathrm{x}$ \\
\hline & CS-2-15 & --- & C28 & 1750 & 20 & 4 & $1800 \mathrm{~s}$ & $x$ & $x$ \\
\hline & CS-2-13 & --- & C29 & 1750 & 25 & 2 & $3600 \mathrm{~s}$ & $x$ & $x$ \\
\hline
\end{tabular}

Long Term Tests for Vehicle Design A.-Samples of the Nextel 312 spring tube thermal barriers were also subjected to long term compression tests in combination with flow tests before and after compression (Table 4). This testing was performed to simulate the effect of a seal held under compression for long periods due to extended ground operations. As shown in Table 3, two test sequences were completed. The flow tests were performed in a manner identical to those for the short term tests previously described. For the 60-day room temperature compression, the seal was installed in a non-instrumented aluminum compression fixture (Figure 8). This fixture consisted of a seal holder with a 0.660 -in. wide by 0.450 in deep groove into which the seal was inserted. Shims that were 0.100 -in. thick were placed on either side of the seal to set the gap. A flat plate was then bolted down on top of the shims so that the sample was compressed approximately $20 \%$ with a 0.100 -in. gap.

Table 4.- Test sequence used for long term tests.

\begin{tabular}{|l|c|c|c|}
\hline \multicolumn{1}{|c|}{ Type of Test } & Delta P & Dwell & Cycles \\
\hline Flow (RT) & $2.0 \mathrm{psig}$ & --- & --- \\
\hline Compression (RT) & --- & 60 days & 1 \\
\hline Flow (RT) & $2.0 \mathrm{psig}$ & --- & --- \\
\hline Compression $\left(1500^{\circ} \mathrm{F}\right)$ & --- & $2200 \mathrm{~s}$ & 1 \\
\hline Flow (RT) & $2.0 \mathrm{psig}$ & --- & --- \\
\hline
\end{tabular}


As shown in Table 4, a high temperature compression test was also conducted on the same sample. For this evaluation, the sample was inserted in the SiC seal holder used for the short term tests. This fixture was then installed inside the furnace and heated to $1500{ }^{\circ} \mathrm{F}$ at a rate of $500{ }^{\circ} \mathrm{F} / \mathrm{hr}$. After temperature equilibration, the load platen was lowered to the approximate starting point defined in the short term tests, and the platen was moved down by $0.135 \mathrm{in}$. at $0.002 \mathrm{in./s}$. Following a $2200 \mathrm{~s}$ dwell, the seal was fully unloaded at $0.002 \mathrm{in.} / \mathrm{s}$. The furnace was allowed to cool, and the seal was then installed in the flow fixture for a final leakage assessment.

\section{Nextel 440 Seal Tests}

Room temperature and high temperature compression tests were also completed on Nextel 440 seal samples intended for use on a second vehicle design (Vehicle B). As shown in Table 3, each test used a unique test

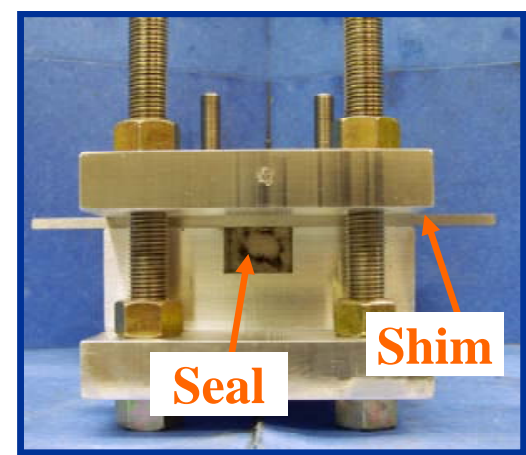

Figure 8.-Photograph of setup used for long-term compression testing. sample. Leakage assessments were conducted before and after each compression test as previously described with the exception of increasing the pressure up to 4 psid in 0.25 psid increments. For these compression evaluations, the samples were inserted in the $\mathrm{SiC}$ seal holder, installed inside the furnace, and heated to the appropriate temperature at $500^{\circ} \mathrm{F} / \mathrm{hr}$. Samples were then loaded at $0.002 \mathrm{in} . / \mathrm{s}$ to the level indicated in the table, held at this level for the appropriate duration, and then fully unloaded at the same rate. This sequence was repeated the prescribed number of cycles shown in Table 3. After furnace cool-down, a leakage assessment was conducted.

\section{Wafer Seal Tests}

Compression tests were conducted at room temperature and high temperature on a stack of 31 AS- $800 \mathrm{Si}_{3} \mathrm{~N}_{4}$ wafers preloaded by four $\mathrm{Si}_{3} \mathrm{~N}_{4}$ compression springs (Figure 9). Leakage evaluation were conducted before and after the compression tests up to 4.0 psid in 0.25 psid increments. For the compression evaluations, a thin ceramic shim was placed in between the wafers and the springs to distribute the load. The sample holder was placed in the furnace, and after reaching the appropriate temperature, the movable platen was lowered until it was in contact with the wafer stack, which was defined as a load of approximately $0.03 \mathrm{lbf} / \mathrm{in}$. After initial contact was established, the wafer stack was loaded per the conditions shown in Table 5. Each load cycle consisted of loading the wafers/springs by 0.050 in. at a rate of $0.001 \mathrm{in./s}$, holding at the compression level for the indicated time, and then unloading at $0.001 \mathrm{in.} / \mathrm{s}$ to the starting point. The same set of wafers and springs was used for all tests.

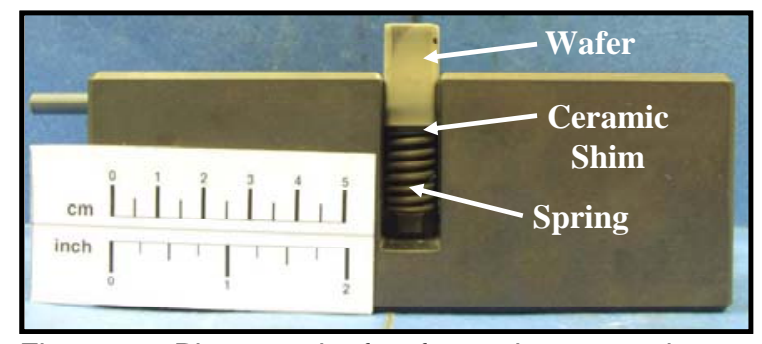

Figure 9.-Photograph of wafer seal compression test setup.

Table 5.--Summary of parameters used for compression testing of wafer seals.

\begin{tabular}{|c|c|c|c|c|c|c|c|c|}
\hline \multirow[t]{2}{*}{ Seal Construction } & \multirow[t]{2}{*}{ Seal ID } & \multirow[t]{2}{*}{ Test ID } & \multirow{2}{*}{$\begin{array}{c}\begin{array}{c}\text { Test } \\
\text { Temperature }\end{array} \\
\left({ }^{\circ} \mathrm{F}\right)\end{array}$} & \multirow{2}{*}{$\begin{array}{c}\text { Compression } \\
\text { (in.) } \\
\end{array}$} & \multirow[t]{2}{*}{ Cycles } & \multirow[t]{2}{*}{ Duration } & \multicolumn{2}{|c|}{$\begin{array}{l}\text { Room Temp. } \\
\text { Flow Tests }\end{array}$} \\
\hline & & & & & & & Before & After \\
\hline \multirow{4}{*}{$\begin{array}{l}\text { AS } 800 \mathrm{Si}_{3} \mathrm{~N}_{4} \text { wafers }+ \\
\qquad \mathrm{Si}_{3} \mathrm{~N}_{4} \text { springs }\end{array}$} & \multirow{4}{*}{$\mathrm{n} / \mathrm{a}$} & $\mathrm{C} 21$ & 70 & 0.050 & 4 & $1800 \mathrm{~s}$ & $\mathrm{x}$ & $x$ \\
\hline & & $\mathrm{C} 24$ & 2200 & 0.050 & 4 & $1800 \mathrm{~s}$ & $x$ & $x$ \\
\hline & & $\mathrm{C} 25$ & 2200 & 0.050 & 2 & $3600 \mathrm{~s}$ & $x$ & $x$ \\
\hline & & C26 & 2200 & 0.050 & 2 & $3600 \mathrm{~s}$ & $x$ & $x$ \\
\hline
\end{tabular}

\section{Finite Element Analyses of Channel Seal}

A summary of the FEA parameters investigated for the design of the superalloy channel seal is presented in Table 6. The design and optimization of the channel seal was completed in an iterative manner with the primary goal of maintaining sufficient margin on the yield strength at temperature while maintaining adequate preload for proper sealing. Secondary objectives were to minimize stresses and optimize wear resistance (through material selection) 
for long-term durability and creep resistance. As illustrated in the table, several factors were examined, including material type, applied load, sheet thickness, type of fixity, and temperature.

The analyses were conducted using either ANSYS Classic v10.0 or ANSYS Workbench v10.0 depending upon element type. With the exception of the initial case and case 7, the channel seal was modeled with quadratic shell elements (SHELL93) for analytical simplicity and computational efficiency. For the exceptions noted, quadratic tetrahedral elements (SOLID187) were used for modeling. All cases were run using a simulated seal unit preload. The materials properties used in the analyses are presented in Table 7.

Table 6.--Summary of parameters examined for channel seal FEA.

\begin{tabular}{|c|c|c|c|c|c|c|c|}
\hline Case & Subcase & $\begin{array}{c}\text { Temperature } \\
\left({ }^{\circ} \mathrm{F}\right) \\
\end{array}$ & $\begin{array}{l}\text { Applied Load } \\
\text { (lbf/in.) }\end{array}$ & Material & $\begin{array}{l}\text { Thickness } \\
\text { (in.) }\end{array}$ & Fixity & Element Type \\
\hline 1 & a & 1500 & 12.5 & Rene 41 & 0.050 & $\begin{array}{c}\text { Fixed } 2 \text { bolt holes in } \\
X, Y, Z\end{array}$ & $\begin{array}{l}\text { Tetrahedral } \\
\text { elements w/ mid- } \\
\text { side nodes }\end{array}$ \\
\hline 2 & a & 70 & 2.0 & IN 718 & 0.050 & $\begin{array}{l}\text { Fixed entire back } \\
\text { surface in } X, Y, Z\end{array}$ & $\begin{array}{c}\text { Structural shell w/ } \\
\text { mid-side nodes }\end{array}$ \\
\hline \multirow{4}{*}{3} & $\mathrm{a}$ & \multirow{4}{*}{70} & \multirow{4}{*}{2.0} & \multirow{2}{*}{ IN 718} & 0.050 & \multirow{4}{*}{$\begin{array}{l}\text { Fixed entire back } \\
\text { surface in } X, Y, Z\end{array}$} & \multirow{4}{*}{$\begin{array}{l}\text { Structural shell w/ } \\
\text { mid-side nodes }\end{array}$} \\
\hline & $\mathrm{b}$ & & & & 0.025 & & \\
\hline & c & & & Rene 41 & 0.025 & & \\
\hline & $d$ & & & Haynes 188 & 0.025 & & \\
\hline \multirow{2}{*}{4} & $\mathrm{a}$ & \multirow{2}{*}{1500} & \multirow{2}{*}{1.3} & Rene 41 & \multirow{2}{*}{0.025} & \multirow{2}{*}{$\begin{array}{l}\text { Fixed } 2 \text { nodes near } \\
\text { bolt holes in } X, Y, Z\end{array}$} & \multirow{2}{*}{$\begin{array}{l}\text { Structural shell w/ } \\
\text { mid-side nodes }\end{array}$} \\
\hline & $\mathrm{b}$ & & & Haynes 188 & & & \\
\hline \multirow[b]{2}{*}{5} & a & 70 & 2.6 & \multirow[b]{2}{*}{ IN 718} & \multirow{2}{*}{0.025} & \multirow{2}{*}{$\begin{array}{c}\text { Fixed } 2 \text { nodes near } \\
\text { bolt holes in } X, 1 \\
\text { node between holes } \\
\text { in } Y, \text { group of nodes } \\
\text { on base in } Z\end{array}$} & \multirow{2}{*}{$\begin{array}{l}\text { Structural shell w/ } \\
\text { mid-side nodes }\end{array}$} \\
\hline & $\mathrm{b}$ & 1500 & 1.7 & & & & \\
\hline \multirow{12}{*}{6} & $\mathrm{a}$ & \multirow{12}{*}{1500} & 1.1 & \multirow{12}{*}{ IN 718} & \multirow{4}{*}{0.025} & \multirow{12}{*}{$\begin{array}{l}\text { Fixed } 2 \text { nodes near } \\
\text { bolt holes in } X, 1 \\
\text { node between holes } \\
\text { in } Y, \text { group of nodes } \\
\text { on base in } Z\end{array}$} & \multirow{12}{*}{$\begin{array}{l}\text { Structural shell w/ } \\
\text { mid-side nodes }\end{array}$} \\
\hline & $\mathrm{b}$ & & 1.7 & & & & \\
\hline & c & & 2.4 & & & & \\
\hline & $d$ & & 3.0 & & & & \\
\hline & $\mathrm{e}$ & & 3.0 & & & & \\
\hline & $f$ & & 4.8 & & & & \\
\hline & $\mathrm{g}$ & & 6.5 & & 0.035 & & \\
\hline & $\mathrm{h}$ & & 8.3 & & & & \\
\hline & $\mathrm{i}$ & & 8.8 & & \multirow{4}{*}{0.050} & & \\
\hline & $j$ & & 13.9 & & & & \\
\hline & $\mathrm{k}$ & & 19.0 & & & & \\
\hline & $\mathrm{I}$ & & 24.1 & & & & \\
\hline \multirow{9}{*}{7} & $a$ & \multirow{9}{*}{1500} & 1.1 & \multirow{9}{*}{ IN 718} & & & \\
\hline & $\mathrm{b}$ & & 2.1 & & 0.025 & & \\
\hline & $\mathrm{c}$ & & 3.6 & & & & \\
\hline & $d$ & & 1.1 & & & Fixed 2 bolt holes in & Tetrahedral \\
\hline & $\mathrm{e}$ & & 2.1 & & $\begin{array}{l}.025+.025 \\
\text { bonded }\end{array}$ & $X, Y, Z$, entire back & elements w/ mid- \\
\hline & $f$ & & 3.6 & & & surface in Z & side nodes \\
\hline & $\mathrm{g}$ & & 1.1 & & & & \\
\hline & $\mathrm{h}$ & & 2.1 & & $\begin{array}{l}.025+.025 \\
\text { laminate }\end{array}$ & & \\
\hline & $\mathrm{i}$ & & 3.6 & & & & \\
\hline & $\mathrm{a}$ & & 0.7 & & & Fixed 2 nodes near & \\
\hline 8 & $\mathrm{~b}$ & 1500 & 1.1 & IN 718 & 0025 & bolt holes in X, Z & Structural shell w/ \\
\hline 8 & $\mathrm{c}$ & 1500 & 1.6 & IN 18 & & between holes in $Y$ & mid-side nodes \\
\hline & $d$ & & 2.0 & & & trans. and rotation & \\
\hline
\end{tabular}

Unless noted otherwise, all channel seals were one layer

Table 7.-Summary of material properties for channel seal FEA.

\begin{tabular}{|c|c|c|c|c|c|c|}
\hline \multirow{2}{*}{ Material } & \multicolumn{2}{|c|}{$E\left(10^{6} \mathrm{psi}\right)$} & \multicolumn{2}{|c|}{ CTE $\left(10^{-6} /{ }^{\circ} \mathrm{F}\right)$} & \multicolumn{2}{|c|}{$\mathrm{YS}_{0.2 \%}(\mathrm{ksi})$} \\
\hline & $70^{\circ} \mathrm{F}$ & $1500^{\circ} \mathrm{F}$ & $70^{\circ} \mathrm{F}$ & $1500^{\circ} \mathrm{F}$ & $70^{\circ} \mathrm{F}$ & $1500^{\circ} \mathrm{F}$ \\
\hline IN $718^{6,7}$ & 29.0 & 21.3 & 6.9 & 8.9 & 150.0 & 57.0 \\
\hline Rene $41^{7,8}$ & 31.6 & 24.1 & 6.2 & 8.5 & 150.0 & 97.9 \\
\hline Haynes $188^{9}$ & 33.6 & 24.3 & 6.6 & 9.2 & 67.3 & 37.4 \\
\hline
\end{tabular}




\section{Results and Discussion}

\section{A. Nextel 312 Seal Tests}

\section{Short Term Tests for Vehicle Design A}

Results from the short term hot compression tests are presented in Figure 10 and summarized in Table 8. Figure 10 presents a plot of seal load as a function of cumulative time for the three repeat experiments in the test sequences. As shown in the graph, the loads generated by the seals dropped significantly (about 80\%) during the first $3000 \mathrm{~s}$ dwell period. This was due to permanent set occurring in the seal as well as compacting of the seal in the groove. Evidence of this could be seen by noting that the seal assumed the shape of the groove after compression. It should be noted that after approximately $2000 \mathrm{~s}$, the load stabilized at about $1 \mathrm{lbf} / \mathrm{in}$., and the rate of reduction was significantly slower.

After flow testing and reinsertion of the seal into the compression fixturing, the seals recovered some of the load during the 2200 s dwell tests. For these tests, the load relaxed ( 30\%), but it did not drop as dramatically as it did in the $3000 \mathrm{~s}$ test. A similar phenomenon was observed for the last test of the sequence (e.g., 4 cycles (@ 200 s dwell). Throughout the testing duration in all of these cases, the seal samples continued to exhibit load carrying capacity thus indicating sustainable sealing capability.

Table 8 presents a summary of the peak and final loads measured during the dwell of each test during the test sequences. As shown in the table, the loads from the first cycle (3000 s) were very close for the three repeat tests, and they dropped off to the same level at the end of the dwell periods. There was

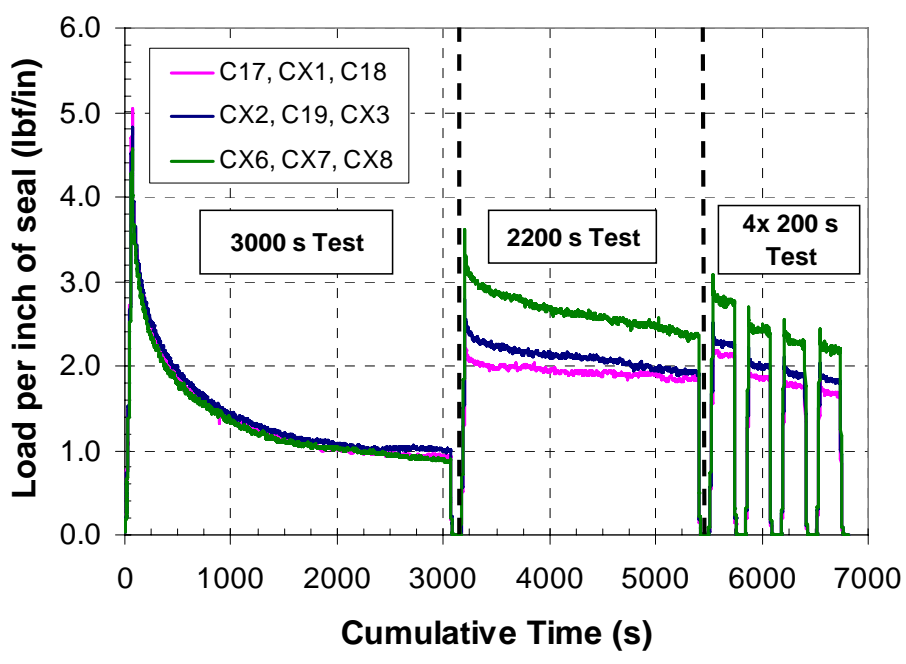

Figure 10.-Plot of seal load as a function of cumulative time at $1500{ }^{\circ} \mathrm{F}$ for each test sequence of the short term Nextel 312 spring tube seal tests.

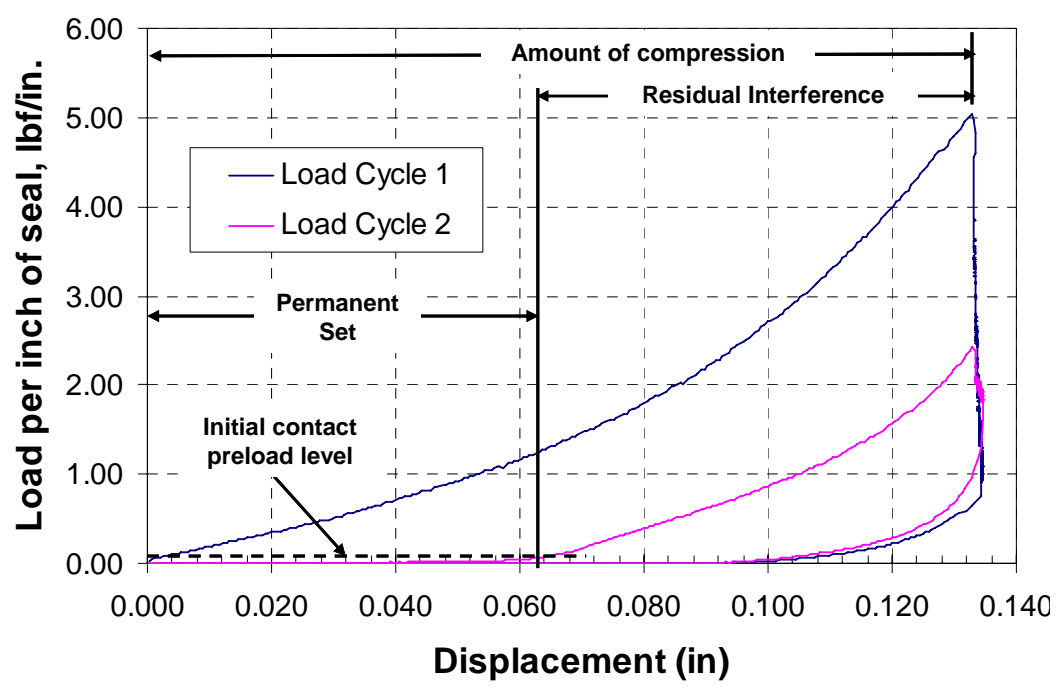

Figure 11.-Plot illustrating definition of residual interference. slightly more variation in loads between the subsequent tests in the test sequences. This may have been due to variations in reinstallation of the seal samples into the test fixturing for the remaining tests. However, the relative amounts of load retention for the subsequent tests were comparable between the three repeat tests.

The residual inference was also calculated for each test and is reported in Table 9. This parameter is a measure of seal resiliency and can provide an estimate of the seal's ability to track gap openings. Residual interference is defined as the following:

$$
\begin{aligned}
& \text { Residual Interference }=\text { Amount of compression }- \text { permanent set } \\
& \% \text { Residual Interference }=(\text { Residual Interference } / \text { Amount of compression }) * 100
\end{aligned}
$$

For the current study, the amount of permanent set was estimated as the point at which the load reached the predefined preload level (i.e., $0.05 \mathrm{lbf} / \mathrm{in}$. of seal length) during a compression test, which indicated the compression platen had contacted the seal. Figure 11 shows a representative seal load v displacement plot and illustrates this concept in graphical form. 


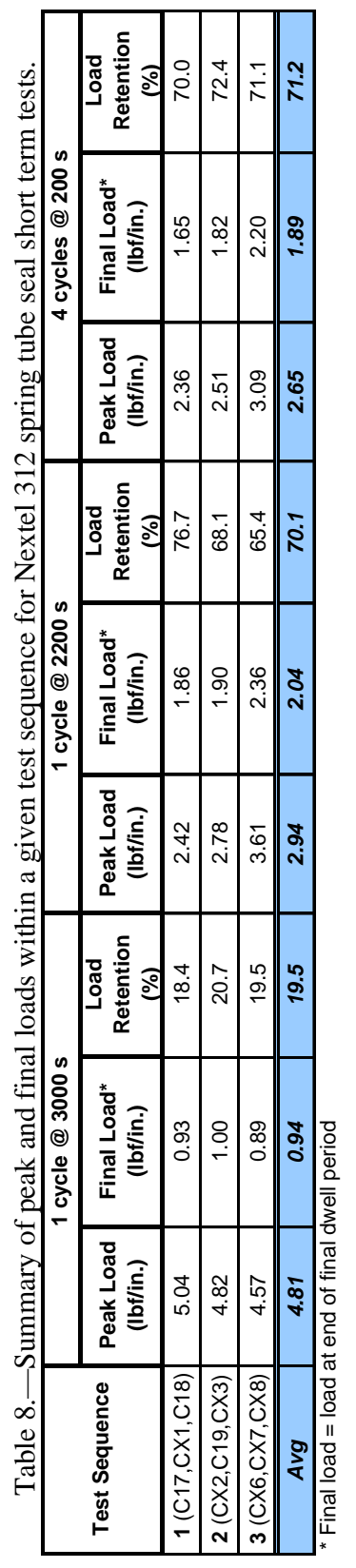

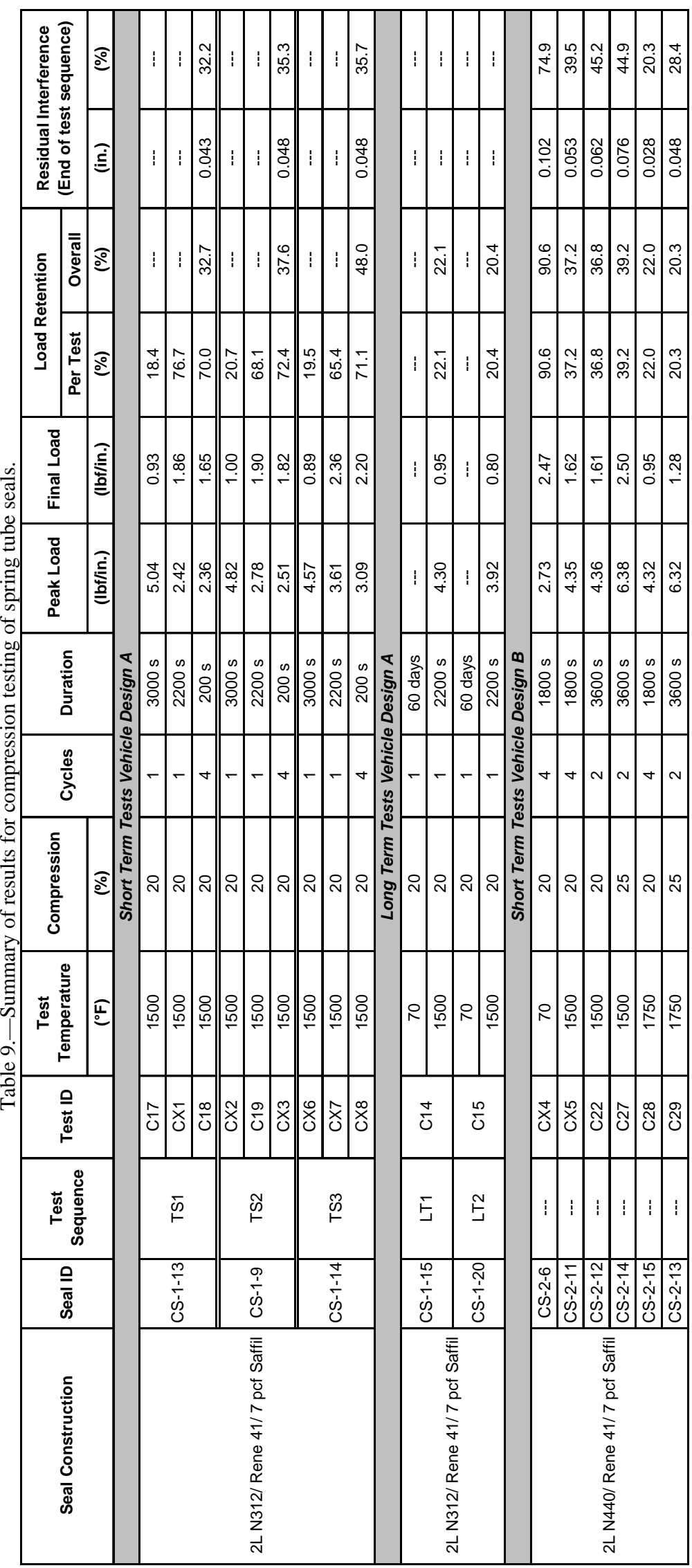


According to the data, the seals exhibited about 0.078 in. (58\%) of residual interference on average after the first test $(3000 \mathrm{~s})$ in the sequence. After the second test (2200 s), the average residual interference was approximately 0.072 in. (53\%). By the end of the third test (4 cycles@ 200 s), the resiliency dropped to about 0.046 in. (34\%) on average. Thus for a single load cycle, the seal would be able to track a gap opening of approximately 0.070 to $0.080 \mathrm{in}$. Alternatively stated, for a nominal starting gap of $0.100 \mathrm{in}$. with the seal installed at $20 \%$ compression, the seal would be able to maintain contact with the opposing surface as long as the gap does not exceed approximately 0.170 to $0.180 \mathrm{in}$.

Figure 12 presents leakage results for the three repeat test sequences. As shown in the graph, the leakage values for the seals in contact with a $\mathrm{C} / \mathrm{C}$ panel ranged between 0.25 to $0.33 \mathrm{SCFM} / \mathrm{in}$. of seal at 2 psid. The current test data demonstrated there was no clear negative impact of high temperature compression testing on seal leakage as long as the seal remained in contact with the adjacent surface (at the gap tested). In fact, in some cases, the leakage appeared to decrease after hot compression testing. This was most evident in the last test sequence (TS3) where flow results after each of the three high temperature compression tests were lower than the initial test.

\section{Long Term Tests for Vehicle Design A}

A plot of seal load versus dwell time at $1500{ }^{\circ} \mathrm{F}$ after a 60-day room temperature compression hold is presented in Figure 13. As noted in this graph and substantiated by Table 9, the amount of load relaxation occurring during the high temperature dwell period was not significantly impacted by the 60-day room temperature compression hold. The extent of reduction in load was comparable for these tests when compared to the short-term tests previously described. Due to the fact that only one load cycle per sample was performed in the Hot Compression Rig, residual interference could not be calculated as a second cycle is needed to establish the amount of permanent set.

The flow restriction ability of the seals did not degrade after either the long term room temperature compression or after the high temperature compression tests (Figure 14). In fact, for both test sequences the trends appear to indicate the leakage resistance actually improved slightly. This could be the result of compaction and densification of the core Saffil material which would better inhibit flow through the seal. As demonstrated in Figure 14, the leakage values for these tests were consistent with the range of values observed from the short term tests, as denoted by the upper and lower bounds in the graph. 


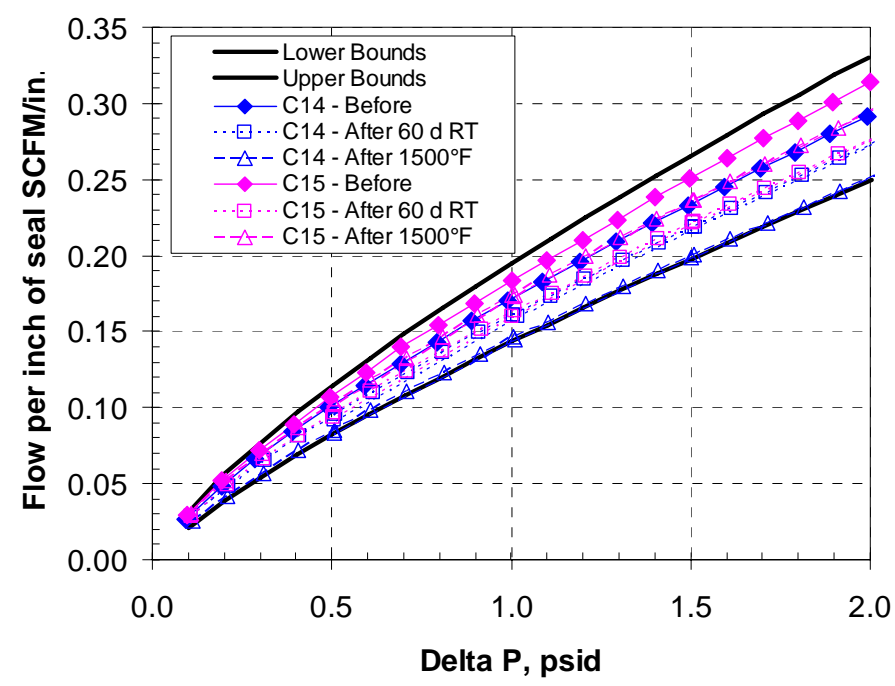

Figure 14.-Plot of room temperature seal leakage against C/C panel before and after long term compression testing of Nextel 312 spring tube seals. Note: Upper and lower bounds were established from max./min. leakage results for short term tests. Before = before compression testing, After $=$ after compression testing.

\section{B. Nextel 440 Seal Tests}

Load versus displacement results for the Nextel 440 spring tube seal tests are presented in Figure 15 and summarized in Table 9. As may be noted in Figure 15, the data are "noisier" than results from other tests. This was due to the load cell recording vibrational pulses originating from an exterior source.

When compared to the compression results of the Nextel 312 spring tube seals, the data indicate that load relaxation was not as significant for the Nextel 440 spring tube seals over similar durations. For example, the load in test CX6 (Nextel 312 seal) relaxed by $80 \%$ whereas for test C22 (Nextel 440 seal), the load dropped by only 63\%. As noted the primary difference between these seal samples was the sheath material. Although the Nextel 440 does have a higher temperature capability (and less boria in the fiber), the difference in fiber strength/creep properties at $1500{ }^{\circ} \mathrm{F}$ for approximately $1 \mathrm{hr}$ are minimal. Instead, the additional boria in the Nextel 312 may have resulted in fibers sticking together and limiting the apparent resiliency of the seal. A similar phenomenon was observed in a previous investigation. $^{3}$

Results from the flow tests conducted on the Nextel 440

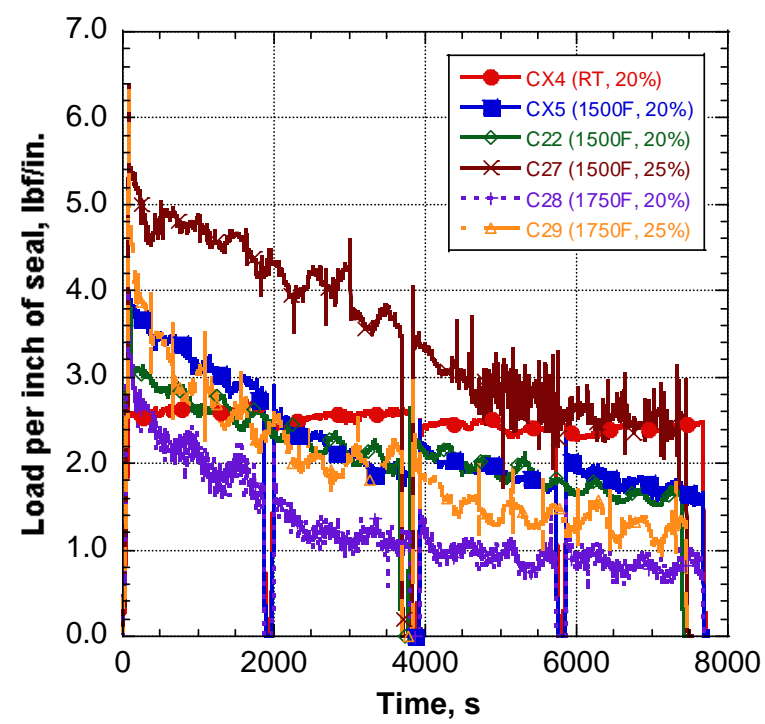

Figure 15.-Plot of seal load as a function of time at $1500^{\circ} \mathrm{F}$ for the short term Nextel 440 spring tube seal tests. seals before and after the compression evaluations are presented in Figure 16. Based upon results from these tests, no significant or consistent change in leakage was observed after high temperature compression testing. In some cases leakage appeared to have increased (C27) and in other cases the flow decreased or remained nearly constant (C22, CX4). The differences are within the range of values based upon variations in experimental setup and measurement uncertainties.

When compared to the flow results on the Nextel 312 seals, the leakage through the Nextel 440 spring tube seals was approximately 10 to $20 \%$ lower. For example, the flow for test C22 after hot compression testing was 
0.20 SCFM/in. at 2 psid. Leakage for comparable Nextel 312 seal tests (C17, CX2, and $\mathrm{CX} 6$ ) ranged from approximately 0.26 to $0.32 \mathrm{SCFM} / \mathrm{in}$. The exact reasons for this trend are unclear, but may be due to a slightly higher sheath density for the Nextel 440 seals as evidenced by greater weights. Overall the leakage values for the Nextel 440 spring tube seal tests varied from $0.18 \mathrm{SCFM} /$ in. to $0.30 \mathrm{SCFM} / \mathrm{in}$. at 2 psid.

\section{Wafer Seal Tests}

A graph presenting load relaxation results for the $\mathrm{Si}_{3} \mathrm{~N}_{4}$ wafers preloaded by $\mathrm{Si}_{3} \mathrm{~N}_{4}$ springs is presented in Figure 17. Table 10 also summarizes the results from these tests. As demonstrated in the plot, the load reacted by the springs did decrease at higher temperatures which was likely due to a temperature-induced modulus decrease. However, it was also interesting to note that the spring constant (and thus load) increased slightly for each subsequent test at $2200^{\circ} \mathrm{F}$, as shown in Table 10 .

Recall that the same wafers and springs were used for all tests and that the wafer stack and springs were preloaded to the same level at initial contact. One possible explanation for the higher stiffness may be due to sintering/creep of the springs, which could result in densification, and therefore a higher modulus. By the end of the tests, the $\mathrm{Si}_{3} \mathrm{~N}_{4}$ springs were 0.010 to $0.020 \mathrm{in}$. shorter than their original free height which indicated densification and/or creep.

When compared to the spring tube seal results, the spring/wafer combinations only show a modest drop in load at high temperatures. In general, for similar durations, the wafer/spring system maintained nearly $80 \%$ of peak loads while the spring tube seals sustained only 20 to $40 \%$ of the initial loads. This is especially encouraging when one considers that the wafer seal systems were tested at temperatures $450{ }^{\circ} \mathrm{F}$ higher than the hottest spring tube seal tests. This also demonstrates why this seal system is targeted for very high temperature applications.

Table 10.-Summary of compression test results for $\mathrm{Si}_{3} \mathrm{~N}_{4}$ wafers preloaded by $\mathrm{Si}_{3} \mathrm{~N}_{4}$ springs.

\begin{tabular}{|c|c|c|c|c|c|c|c|c|c|c|c|}
\hline \multirow{2}{*}{$\begin{array}{c}\text { Seal } \\
\text { Construction }\end{array}$} & \multirow[t]{2}{*}{ Test ID } & \multirow{2}{*}{$\begin{array}{c}\begin{array}{c}\text { Test } \\
\text { Temperature }\end{array} \\
\left({ }^{\circ} \mathrm{F}\right)\end{array}$} & \multirow{2}{*}{\begin{tabular}{|c} 
Compression \\
(in.)
\end{tabular}} & \multirow[t]{2}{*}{ Cycles } & \multirow[t]{2}{*}{ Duration } & \multirow{2}{*}{\begin{tabular}{|c|}
$\begin{array}{l}\text { Peak } \\
\text { Load }\end{array}$ \\
(lbf/in.) \\
\end{tabular}} & \multirow{2}{*}{\begin{tabular}{|c|}
$\begin{array}{c}\text { Final } \\
\text { Load }\end{array}$ \\
(lbf/in.) \\
\end{tabular}} & \multirow{2}{*}{\begin{tabular}{|c|}
$\begin{array}{c}\text { Load } \\
\text { Retention }\end{array}$ \\
$(\%)$ \\
\end{tabular}} & \multirow{2}{*}{\begin{tabular}{|c|}
$\begin{array}{c}\text { Spring* } \\
\text { Constant }\end{array}$ \\
(lbflin./in.)
\end{tabular}} & \multicolumn{2}{|c|}{$\begin{array}{l}\text { Residual Interference } \\
\text { (End of test sequence) }\end{array}$} \\
\hline & & & & & & & & & & (in.) & (\%) \\
\hline \multicolumn{12}{|c|}{ Short Term Tests Vehicle Design B } \\
\hline \multirow{4}{*}{$\begin{array}{c}\mathrm{AS}^{800} \mathrm{Si}_{3} \mathrm{~N}_{4} \\
\text { wafers + } \\
\mathrm{Si}_{3} \mathrm{~N}_{4} \text { springs }\end{array}$} & $\mathrm{C} 21$ & 70 & 0.050 & 4 & $1800 \mathrm{~s}$ & 2.30 & 2.25 & 97.6 & 45.7 & 0.050 & 100.0 \\
\hline & $\mathrm{C} 24$ & 2200 & 0.050 & 4 & $1800 \mathrm{~s}$ & 1.89 & 1.43 & 75.5 & 38.1 & 0.039 & 77.2 \\
\hline & $\mathrm{C} 25$ & 2200 & 0.050 & 2 & $3600 \mathrm{~s}$ & 2.11 & 1.71 & 81.2 & 42.2 & 0.045 & 88.8 \\
\hline & $\mathrm{C} 26$ & 2200 & 0.050 & 2 & $3600 \mathrm{~s}$ & 2.16 & 1.82 & 83.9 & 43.8 & 0.046 & 91.2 \\
\hline
\end{tabular}

*Note: Spring constant is reported as lbf load per inch of seal per inch of displacement. 
A plot of flow results for the wafer/spring seal systems evaluated against a $C / C$ panel is presented in Figure 18. As may be noted, a consistent trend in seal leakage before and after compression testing was not apparent. The range of data can likely be attributed to experimental variation. As has been previously reported, the leakage values for the wafers were significantly lower than those for the spring tube seals. ${ }^{5,10}$ For the current tests against a CMC surface, the leakage values across the wafer seals were approximately $1 / 3$ of those for the spring tube seals. This again illustrates the performance benefits of this seal system for demanding applications.

\section{Finite Element Analyses of Channel Seal}

Table 11 presents a summary of the results from the finite element analyses for the channel seal in terms of total deflection (including approximately 0.040 in. of thermal growth) at the opening of the seal and peak von Mises stresses. For the proposed

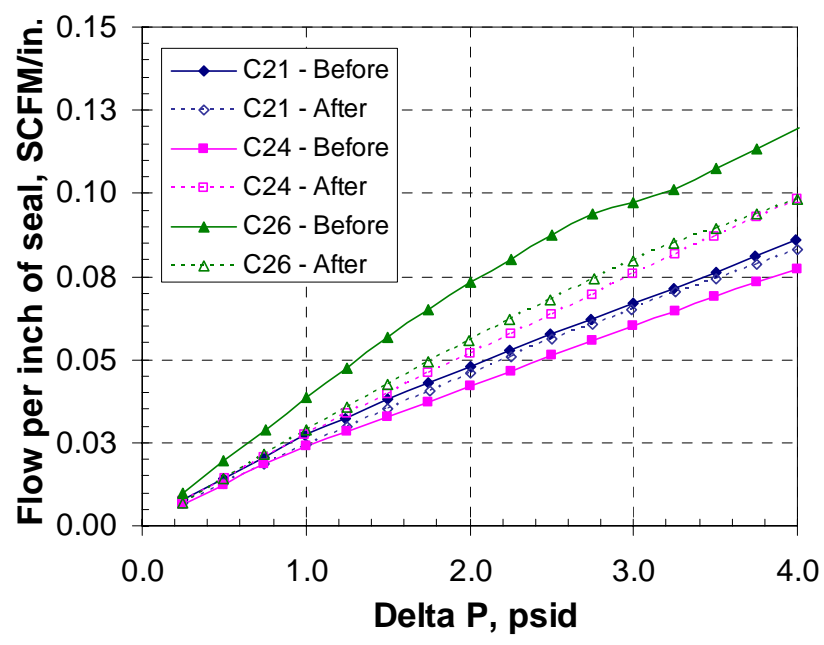

Figure 18.-Plot of room temperature seal leakage against $\mathrm{C} / \mathrm{C}$ panel before and after compression testing of $\mathrm{Si}_{3} \mathrm{~N}_{4}$ wafer/spring seal system. Before $=$ before compression testing, After $=$ after compression testing. application, the opening of the channel seal mates against an IN-718 torque tube.

For the initial FEA investigations (Cases 1 through 4), materials with excellent elevated temperature strength properties (i.e., René 41, IN-718) and/or good wear resistance (i.e., Haynes 188) were selected. Haynes 188, a Cobased alloy, was later eliminated due to lower yield strength at elevated temperatures and a higher CTE than the torque tube material, which could result in loss of sealing capability. To reduce friction and wear with the other superalloys, hard face tribological coatings, such as NASA PM304, could be applied to the torque tube or seal. ${ }^{11}$

While the René 41 has significantly higher yield strength at $1500^{\circ} \mathrm{F}$, it was estimated a seal fabricated from this would experience approximately $20 \%$ higher stresses due to a lower CTE and higher modulus at temperature when compared to IN-718. Therefore, further analyses (Cases 5 through 8) were concentrated on IN-718 so that the channel seal and torque tube would grow and contract at similar rates and thus minimize stresses. However, due to its excellent high temperature strength, a René 41 channel seal may be revisited at a later date.

The effect of IN-718 material thickness (Case 6) on peak von Mises stresses at various deflection levels is presented in Figure 19. As shown, the 0.025-in. thick sheet was the only candidate to remain under the maximum yield stress (YS) level at $1500{ }^{\circ} \mathrm{F}$ for IN-718 (denoted by horizontal red line in graphs) up to nearly $25 \%$ deflection. A 0.035 -in thick channel seal remained under the maximum yield stress level up to approximately $17 \%$ deflection and also offered higher preload values for better sealing (Table 11). Figure 19 also illustrates that the stresses increase linearly with the amount of deflection at the opening of the seal. This is consistent with simple cantilever beam theory which states that for a given thickness, the stress varies linearly with maximum defection (Eq. (1)).

$$
\sigma_{\max }=\frac{3 E \omega_{\max } t}{2 L^{2}}
$$

Where

$$
\begin{aligned}
& \sigma_{\max }=\text { Maximum stress } \\
& E=\text { Young's modulus } \\
& \omega_{\max }=\text { Maximum half-deflection on end } \\
& t=\text { Material thickness } \\
& L=\text { Length of beam element }
\end{aligned}
$$

As evident in Equation (1), the stress is also directly proportional to the material thickness, which is also demonstrated in Figure 20. 
Table 11.- - Summary of peak von Mises stresses for channel seal FEA cases.

\begin{tabular}{|c|c|c|c|c|c|c|c|c|c|c|}
\hline \multirow{2}{*}{ Case } & \multirow{2}{*}{ Subcase } & \multirow{2}{*}{$\begin{array}{c}\text { Temperature } \\
\left({ }^{\circ} \mathrm{F}\right)\end{array}$} & \multirow{2}{*}{$\begin{array}{l}\text { Applied Load } \\
\text { (Ibf/in.) }\end{array}$} & \multirow{2}{*}{ Material } & \multirow{2}{*}{$\begin{array}{l}\text { Thickness } \\
\text { (in.) }\end{array}$} & \multirow{2}{*}{ Fixity } & \multirow{2}{*}{ Element Type } & \multicolumn{2}{|c|}{ Total Deflec. } & \multirow{2}{*}{$\begin{array}{l}\text { Peak von Mises } \\
\text { Stress (ksi) }\end{array}$} \\
\hline & & & & & & & & (in.) & (\%) & \\
\hline 1 & $\mathrm{a}$ & 1500 & 12.5 & Rene 41 & 0.050 & $\begin{array}{c}\text { Fixed } 2 \text { bolt holes in } \\
X, Y, Z\end{array}$ & $\begin{array}{c}\text { Tetrahedral } \\
\text { elements w/ mid- } \\
\text { side nodes }\end{array}$ & 0.535 & 18 & 68.0 \\
\hline 2 & a & 70 & 2.0 & IN 718 & 0.050 & $\begin{array}{l}\text { Fixed entire back } \\
\text { surface in } X, Y, Z\end{array}$ & $\begin{array}{l}\text { Structural shell w/ } \\
\text { mid-side nodes }\end{array}$ & 0.044 & 1 & 10.3 \\
\hline \multirow{4}{*}{3} & $\mathrm{a}$ & \multirow{4}{*}{70} & \multirow{4}{*}{2.0} & \multirow{2}{*}{ IN 718} & 0.050 & \multirow{4}{*}{$\begin{array}{l}\text { Fixed entire back } \\
\text { surface in } X, Y, Z\end{array}$} & \multirow{4}{*}{$\begin{array}{l}\text { Structural shell w/ } \\
\text { mid-side nodes }\end{array}$} & 0.044 & 1 & 10.3 \\
\hline & $\mathrm{b}$ & & & & 0.025 & & & 0.350 & 12 & 41.5 \\
\hline & $\mathrm{c}$ & & & Rene 41 & 0.025 & & & 0.318 & 11 & 41.1 \\
\hline & $\mathrm{d}$ & & & Haynes 188 & 0.025 & & & 0.300 & 10 & 41.1 \\
\hline \multirow{2}{*}{4} & $\mathrm{a}$ & \multirow{2}{*}{1500} & \multirow{2}{*}{1.3} & Rene 41 & \multirow{2}{*}{0.025} & \multirow{2}{*}{$\begin{array}{l}\text { Fixed } 2 \text { nodes near } \\
\text { bolt holes in } X, Y, Z\end{array}$} & \multirow{2}{*}{$\begin{array}{l}\text { Structural shell w/ } \\
\text { mid-side nodes }\end{array}$} & 0.450 & 15 & 25.4 \\
\hline & $b$ & & & Haynes 188 & & & & 0.458 & 15 & 25.4 \\
\hline \multirow{2}{*}{5} & $\mathrm{a}$ & 70 & 2.6 & \multirow{2}{*}{ IN 718} & \multirow{2}{*}{0.025} & $\begin{array}{l}\text { Fixed } 2 \text { nodes near } \\
\text { bolt holes in } X, 1\end{array}$ & Structural shell wl & 0.450 & 15 & 52.6 \\
\hline & $b$ & 1500 & 1.7 & & & $\begin{array}{l}\text { in } Y, \text { group of nodes } \\
\text { on base in } Z\end{array}$ & mid-side nodes & 0.450 & 15 & 34.9 \\
\hline & $a$ & & 1.1 & & & & & 0.300 & 10 & 22.0 \\
\hline & $b$ & & 1.7 & & 0025 & & & 0.450 & 15 & 34.9 \\
\hline & $\mathrm{c}$ & & 2.4 & & $0.0<3$ & & & 0.600 & 20 & 47.7 \\
\hline & $\mathrm{d}$ & & 3.0 & & & & & 0.750 & 25 & 60.5 \\
\hline & $\mathrm{e}$ & & 3.0 & & & Fixed 2 nodes near & & 0.300 & 10 & 30.8 \\
\hline 6 & $f$ & 1500 & 4.8 & IN 718 & 0.035 & bolt holes in X, 1 & Structural shell w/ & 0.450 & 15 & 48.7 \\
\hline 6 & $\mathrm{~g}$ & 1500 & 6.5 & $\operatorname{IN} / 18$ & 0.035 & $\begin{array}{l}\text { node between noles } \\
\text { in } Y \text {, group of nodes }\end{array}$ & mid-side nodes & 0.600 & 20 & 66.6 \\
\hline & $\mathrm{h}$ & & 8.3 & & & on base in $Z$ & & 0.750 & 25 & 84.5 \\
\hline & $\mathrm{i}$ & & 8.8 & & & & & 0.300 & 10 & 44.0 \\
\hline & $\mathrm{j}$ & & 13.9 & & 0.050 & & & 0.450 & 15 & 69.8 \\
\hline & $\mathrm{k}$ & & 19.0 & & & & & 0.600 & 20 & 95.4 \\
\hline & 1 & & 24.1 & & & & & 0.750 & 25 & 121.0 \\
\hline & $a$ & & 1.1 & & & & & 0.322 & 11 & 23.3 \\
\hline & $\mathrm{b}$ & & 2.1 & & 0.025 & & & 0.550 & 18 & 42.3 \\
\hline & $\mathrm{c}$ & & 3.6 & & & & & 0.920 & 31 & 73.0 \\
\hline & $\mathrm{d}$ & & 1.1 & & & Fixed 2 bolt holes in & Tetrahedral & 0.182 & 6 & 16.7 \\
\hline 7 & $\mathrm{e}$ & 1500 & 2.1 & IN 718 & $\begin{array}{c}.025+.025 \\
\text { bonded }\end{array}$ & $\mathrm{X}, \mathrm{Y}, \mathrm{Z}$, entire back & elements w/ mid- & 0.296 & 10 & 30.2 \\
\hline & $f$ & & 3.6 & & & surface in Z & side nodes & 0.482 & 16 & 52.2 \\
\hline & $\mathrm{g}$ & & 1.1 & & & & & 0.266 & 9 & 17.1 \\
\hline & $\mathrm{h}$ & & 2.1 & & $\begin{array}{l}.025+.025 \\
\text { laminate }\end{array}$ & & & 0.452 & 15 & 31.0 \\
\hline & $\mathrm{i}$ & & 3.6 & & & & & 0.750 & 25 & 53.4 \\
\hline & $\mathrm{a}$ & & 0.7 & & & Fixed 2 nodes near & & 0.300 & 10 & 14.1 \\
\hline 8 & $\mathrm{~b}$ & 1500 & 1.1 & IN 718 & 0025 & bolt holes in X, Z & Structural shell w/ & 0.450 & 15 & 22.2 \\
\hline 0 & $\mathrm{c}$ & 1000 & 1.6 & 110710 & 0.025 & between holes in $Y$ & mid-side nodes & 0.600 & 20 & 30.3 \\
\hline & $d$ & & 2.0 & & & trans. and rotation & & 0.750 & 25 & 38.5 \\
\hline
\end{tabular}

Unless noted otherwise, all channel seals were one layer

In order to further reduce stress levels, a reinforced laminate design (shown in Figure 5) was also evaluated in Case 7. For the laminate analysis, a non-linear contact method which permitted relative sliding between the sheets was used to simulate this interface. The results from this analysis are presented in Figure 21. For comparison, a similar case where the two laminates were bonded together is also plotted as well as the baseline case with a single 0.025 -in. thick sheet. As demonstrated in this plot, the laminate reduced the stress levels by approximately $10 \%$ versus the baseline case.

A set of final evaluations (Cases 8a-8d) were performed in which the back face of the seal was less constrained, which permitted a slight rearward deflection at this surface near the radius areas. The results from this analysis are presented in Figure 22, and a schematic illustrating the deflection is shown in Figure 23. For the cases where the seal was only constrained at the bolt holes, the stresses were reduced by approximately $35 \%$. These cases proved to be the most attractive as the stresses approached the lower levels required for good creep life. In this configuration, the seal can accommodate up to 0.75 in. of deflection with a seal contact load of approximately $2.0 \mathrm{lbf} / \mathrm{in}$. and a corresponding stress of $38.5 \mathrm{ksi}$, well within the yield stress for IN-718 at $1500{ }^{\circ} \mathrm{F}$ (Case 8d). Alternatively, for longer creep life, the seal can follow up to $0.30 \mathrm{in}$. of defection with a contact load of $0.7 \mathrm{lbf} / \mathrm{in}$. and a peak von Mises stress of $14.1 \mathrm{ksi}$ (Case 8a). In addition, the majority of the backside surface still maintained good contact with the opposing surface for proper sealing. 


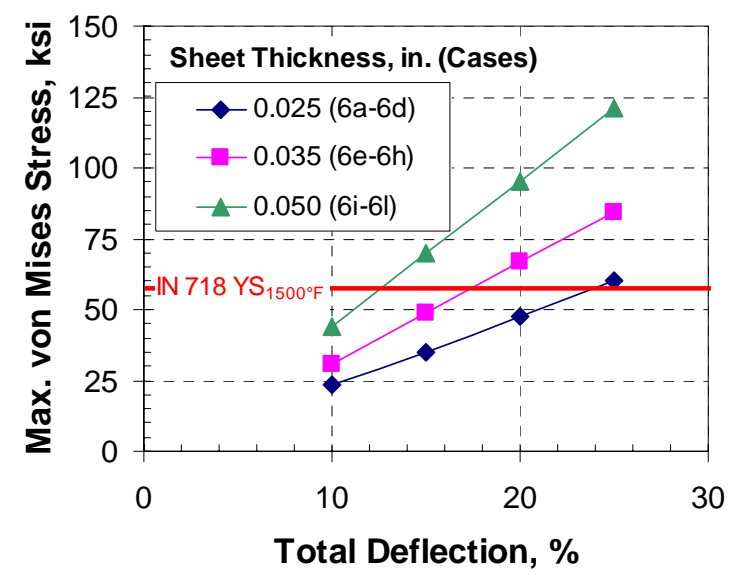

Figure 19.-Plot of maximum von Mises stress at $1500^{\circ} \mathrm{F}$ as a function of total deflection for various IN-718 material sheet thicknesses. Red line denotes approximate yield strength of IN-718 at $1500{ }^{\circ} \mathrm{F}$.

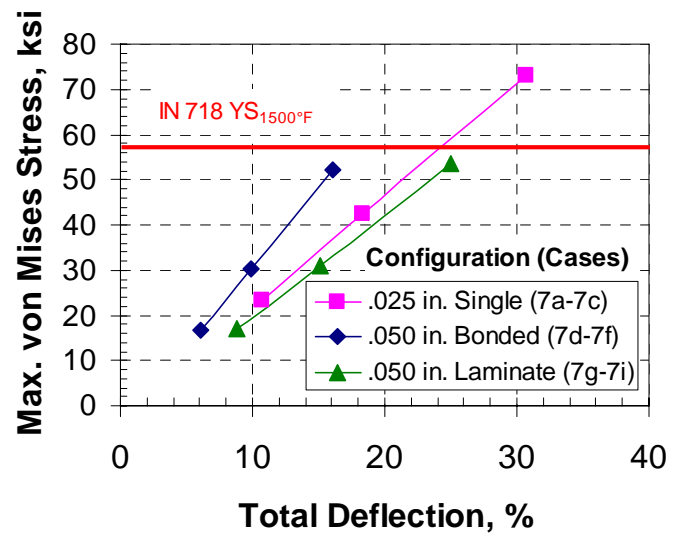

Figure 21.-Plot of maximum von Mises stress at $1500^{\circ} \mathrm{F}$ as a function of total deflection for IN-718 single thickness versus reinforced laminate designs. Red line denotes approximate yield strength of IN-718 at $1500^{\circ} \mathrm{F}$.

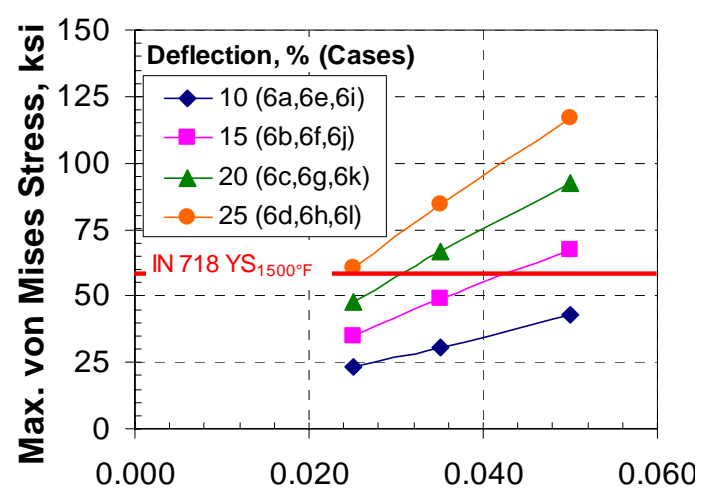

Thickness, in.

Figure 20.-Plot of maximum von Mises stress at $1500^{\circ} \mathrm{F}$ as a function of IN-718 material sheet thickness for various total deflection levels. Red line denotes yield approximate strength of IN-718 at $1500^{\circ} \mathrm{F}$.

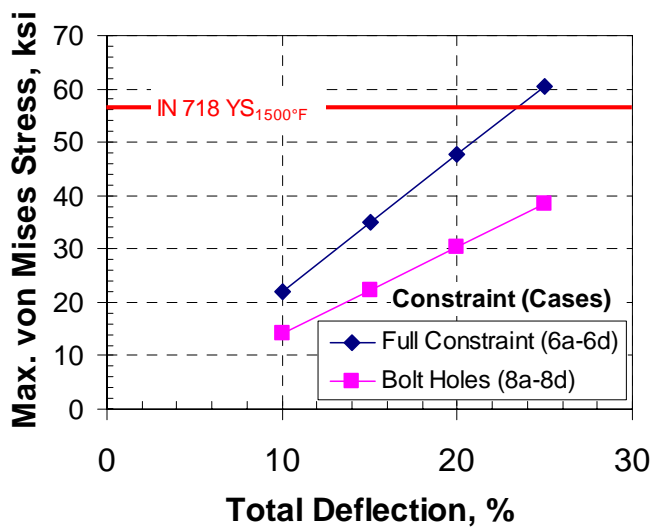

Figure 22.-Plot of maximum von Mises stress at $1500^{\circ} \mathrm{F}$ for IN-718 channel seal as a function of total deflection for various boundary constraint conditions. Red line denotes approximate yield strength of IN-718 at $1500{ }^{\circ} \mathrm{F}$. 


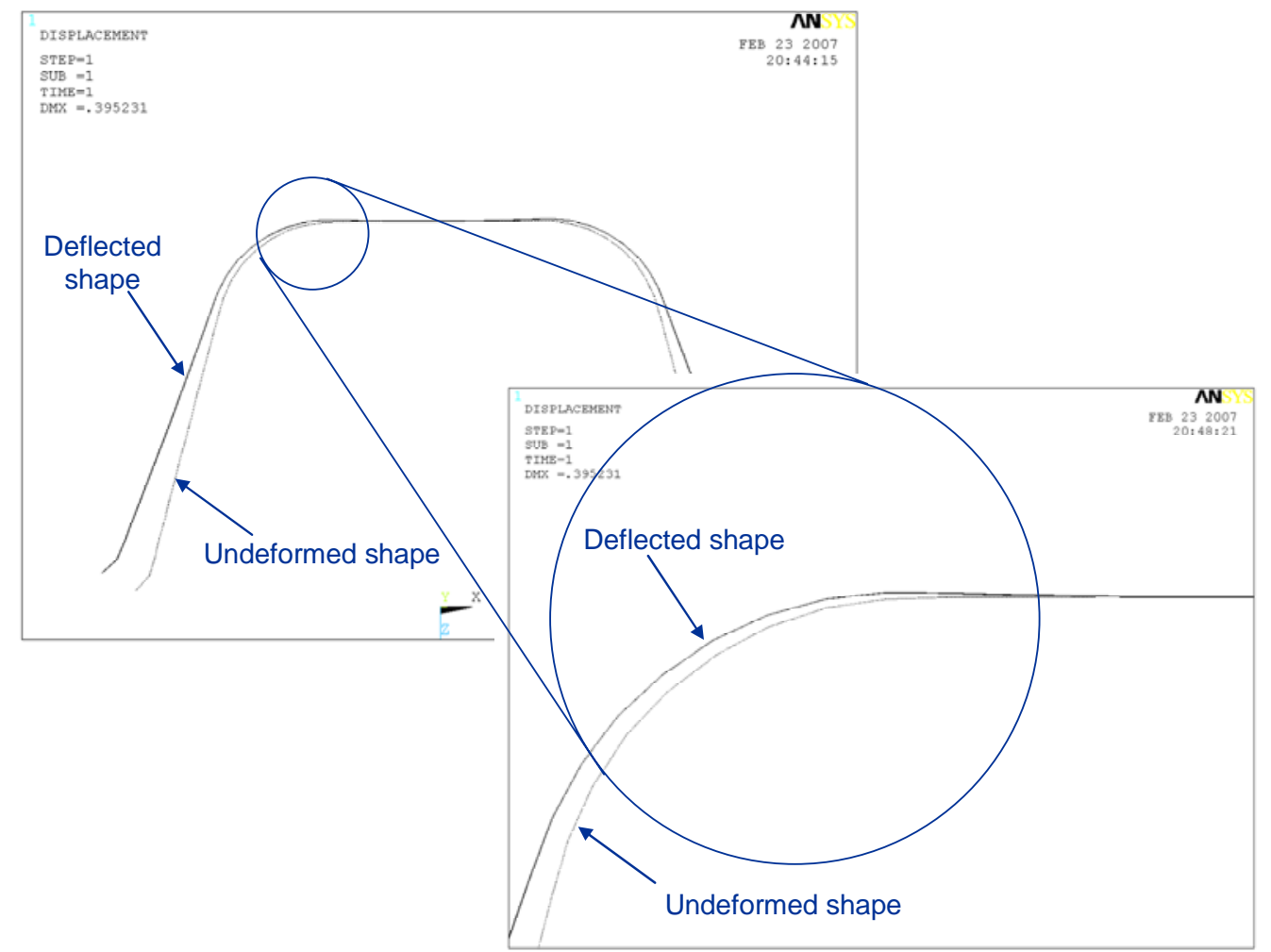

Figure 23.-Schematic illustrating deflection of channel seal at radius area due to reduced constraint.

\section{Conclusions}

Hypersonic vehicles require high temperature airframe seals due to the intense aerodynamic heating generated during flight. In this study, both spring tube thermal barriers and wafer seal systems were evaluated using relevant hypersonic test conditions (temperatures, pressures, etc.). Based upon this testing, the following conclusions were noted:

(1) Nextel 312 thermal barriers with a René 41 spring tube demonstrated acceptable compression performance at temperatures up to $1500^{\circ} \mathrm{F}$. Multi-cycle shorter term tests (on the order of hours) did show evidence of moderate load relaxation, but maintained suitable resiliency. After high temperature compression testing, the seals did not exhibit significant degradation in leakage resistance when tested against a C/C CMC panel. Testing after long term (e.g., 60-days) compression at room temperature did not show a substantial reduction in either load retention or flow blocking performance when compared to the shorter term tests.

(2) Nextel 440 thermal barriers with a René 41 spring tube exhibited respectable compression performance at temperatures up to $1750{ }^{\circ} \mathrm{F}$. Multi-cycle short term tests conducted at similar conditions demonstrated better load retention for the Nextel 440 seals than the Nextel 312 samples (35 to $40 \%$ load retention versus 19 to $20 \%$ load retention, respectively). In addition, leakage values were approximately 10 to $20 \%$ less on average with the Nextel 440 samples both before and after high temperature compression evaluations. This may have been due to a slightly higher Nextel 440 sheath density versus the Nextel 312 sheath density.

(3) Silicon nitride (AS-800) wafer seals preloaded by NHK silicon nitride compression springs displayed excellent compression performance up to $2200^{\circ} \mathrm{F}$. Over durations similar to those used for the spring tube thermal barriers and at temperatures which were more than $400{ }^{\circ} \mathrm{F}$ hotter, the wafer/spring system maintained nearly $80 \%$ of peak loads. In addition, the flow through the wafer seals was only $1 / 3$ of the flow through the spring tube seals, even after high temperature compression testing. 
(4) An iterative finite element analysis approach was successfully conducted on several superalloy channel seal designs for a dynamic seal application. The analyses results were consistent with simple cantilever beam theory and followed the predicted trends relative to deflection, sheet thickness, etc. The evaluations resulted in the preliminary identification of a suitable configuration which consisted of a thin sheet (0.025 in.) of IN-718 attached to minimize constraint of the base section/back face. Using this design, maximum von Mises stresses at $1500{ }^{\circ} \mathrm{F}$ were below $40 \mathrm{ksi}$ at a $25 \%$ deflection across the opening of the seal which is less than the yield strength of IN-718 at this temperature (57 ksi).

\section{References}

${ }^{1}$ Taylor, S.C., DeMange, J.J., Dunlap, P.H., and Steinetz, B.M., "Evaluation of High Temperature Knitted Spring Tubes for Structural Seal Applications,” NASA TM-2004-213183, AIAA-2004-3890, September 2004.

${ }^{2}$ Taylor, S.C., DeMange, J.J., Dunlap, P.H., and Steinetz, B.M., "Further Investigations of High Temperature Knitted Spring Tubes for Advanced Control Surface Seal Applications,” AIAA-2005-4154, July 2005.

${ }^{3}$ DeMange, J.J., Dunlap, P.H., and Steinetz B.M., "Improved Seals for High Temperature Airframe Applications," NASA/TM-2006-214465, AIAA-2006-4935-590, October 2006.

${ }^{4}$ Dunlap, P.H., Steinetz, B.M., and DeMange, J.J., “Further Investigations of Hypersonic Engine Seals,” NASA/TM-2004213188, August 2004.

${ }^{5}$ Dunlap, P.H., Steinetz, B.M., DeMange, J.J., and Taylor, S.C., “Toward an Improved Hypersonic Engine Seal,” NASA/TM2003-212531, AIAA-2003-4834, July 2003.

${ }^{6}$ Inconel Alloy 718 Datasheet, Publication Number SMC-045, Special Metals, Corp., 2004.

${ }^{7}$ Metallic Materials and Elements for Aerospace Vehicle Structures, MIL-HDBK-5J, Dept. of Defense, 2003.

${ }^{8}$ Haynes R-41 Alloy Datasheet, Publication Number H3056A, Haynes International, Inc., 2002.

${ }^{9}$ Haynes 188 Alloy Datasheet, Publication Number H3001B, Haynes International, Inc., 2000.

${ }^{10}$ Dunlap, P.H., DeMange, J.J., and Steinetz, B.M., "Performance Evaluations of Ceramic Wafer Seals,” NASA/TM-2006214416, AIAA-2006-4934, November 2006.

${ }^{11}$ Dellacorte, C., Lukaszewicz, V., Valco, M.J., Radil, K.C., and Heshmat, H., "Performance and Durability of High Temperature Foil Air Bearings for Oil-Free Turbomachinery,” NASA/TM-2000-209187/REV1, March 2000. 


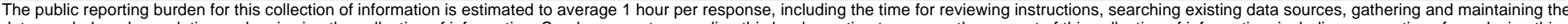

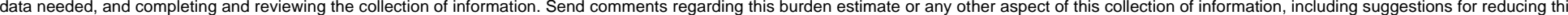

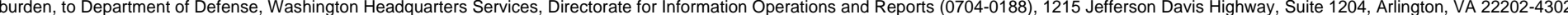

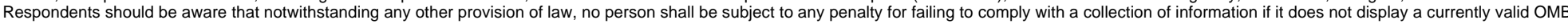
control number.

PLEASE DO NOT RETURN YOUR FORM TO THE ABOVE ADDRESS.

\section{REPORT DATE $(D D-M M-Y Y Y Y)$ \\ 2. REPORT TYPE \\ 3. DATES COVERED (From - To)}

01-10-2007

\section{TITLE AND SUBTITLE}

Technical Memorandum

An Evaluation of High Temperature Airframe Seals for Advanced Hypersonic Vehicles

6. AUTHOR(S)

DeMange, Jeffrey, J.; Dunlap, Patrick, H.; Steinetz, Bruce, M.; Drlik, Gary, J.

5a. CONTRACT NUMBER

5b. GRANT NUMBER

5c. PROGRAM ELEMENT NUMBER

\section{5d. PROJECT NUMBER}

5e. TASK NUMBER

5f. WORK UNIT NUMBER

WBS 659877.02.03.0529.01

\section{PERFORMING ORGANIZATION NAME(S) AND ADDRESS(ES)}

National Aeronautics and Space Administration

\section{PERFORMING ORGANIZATION}

REPORT NUMBER

John H. Glenn Research Center at Lewis Field

E-16229

Cleveland, Ohio 44135-3191

\section{SPONSORING/MONITORING AGENCY NAME(S) AND ADDRESS(ES)}

National Aeronautics and Space Administration

Washington, DC 20546-0001

$\begin{aligned} & \text { 10. SPONSORING/MONITORS } \\ & \text { ACRONYM(S) } \\ & \text { NASA }\end{aligned}$
$\begin{aligned} & \text { 11. SPONSORING/MONITORING } \\ & \text { REPORT NUMBER } \\ & \text { NASA/TM-2007-215043; AIAA-2007- } \\ & 5743\end{aligned}$

\section{DISTRIBUTIONIAVAILABILITY STATEMENT}

Unclassified-Unlimited

Subject Category: 37

Available electronically at http://gltrs.grc.nasa.gov

This publication is available from the NASA Center for AeroSpace Information, 301-621-0390

\section{SUPPLEMENTARY NOTES}

\section{ABSTRACT}

High temperature seals are required for advanced hypersonic airframe applications. In this study, both spring tube thermal barriers and innovative wafer seal systems were evaluated under relevant hypersonic test conditions (temperatures, pressures, etc.) via high temperature compression testing and room temperature flow assessments. Thermal barriers composed of a Rene 41 spring tube filled with Saffil insulation and overbraided with a Nextel 312 sheath showed acceptable performance at $1500{ }^{\circ} \mathrm{F}$ in both short term and longer term compression testing. Nextel 440 thermal barriers with Rene 41 spring tubes and Saffil insulation demonstrated good compression performance up to $1750^{\circ} \mathrm{F}$. A silicon nitride wafer seal/compression spring system displayed excellent load performance at temperatures as high as $2200^{\circ} \mathrm{F}$ and exhibited room temperature leakage values that were only 1/3 those for the spring tube rope seals. For all seal candidates evaluated, no significant degradation in leakage resistance was noted after high temperature compression testing. In addition to these tests, a superalloy seal suitable for dynamic seal applications was optimized through finite element techniques.

\section{SUBJECT TERMS}

Seals; Flow; Test; High temperature

\begin{tabular}{|l|l|l|l|}
\hline \multicolumn{2}{|l|}{ 16. SECURITY CLASSIFICATION OF: } & $\begin{array}{l}\text { 17. LIMITATION OF } \\
\text { ABSTRACT }\end{array}$ \\
\begin{tabular}{|l|l|} 
a. REPORT & b. ABSTRACT \\
$U$
\end{tabular} & $\begin{array}{l}\text { c. THIS } \\
\text { PAGE } \\
\text { U }\end{array}$ & UU \\
\hline
\end{tabular}

18. NUMBER
OF
PAGES
24
19a. NAME OF RESPONSIBLE PERSON STI Help Desk (email:help@sti.nasa.gov) 19b. TELEPHONE NUMBER (include area code) 301-621-0390



